University of Chicago Law School

Chicago Unbound

Journal Articles

Faculty Scholarship

2009

\title{
The Disintegration of Intellectual Property - A Classical Liberal Response to a Premature Obituary
}

Richard A. Epstein

Follow this and additional works at: https://chicagounbound.uchicago.edu/journal_articles

Part of the Law Commons

\section{Recommended Citation}

Richard A. Epstein, "The Disintegration of Intellectual Property - A Classical Liberal Response to a Premature Obituary," 62 Stanford Law Review 455 (2009).

This Article is brought to you for free and open access by the Faculty Scholarship at Chicago Unbound. It has been accepted for inclusion in Journal Articles by an authorized administrator of Chicago Unbound. For more information, please contact unbound@law.uchicago.edu. 


\title{
THE DISINTEGRATION OF INTELLECTUAL PROPERTY? A ClASSICAL LIBERAL RESPONSE TO A PREMATURE OBITUARY
}

\author{
Richard A. Epstein*
}

This Article plays off the title of Thomas Grey's well-known article, The Disintegration of Property, which argued in part that the ceaseless consensual fragmentation and recombination of property rights revealed some inner incoherence of the underlying private property institutions. I take the opposite position and treat this supposed disintegration of private property as evidence of its robust nature, not only for land but for all forms of intellectual property. Low transaction costs facilitate the creation of efficient regimes of property rights. I use this framework to critique modern intellectual property rights cases that limit the use of injunctive relief in intellectual property cases, impose limits on the terms of private licenses of intellectual property, and compromise the protection that intellectual property receives against government confiscation.

One common theme links these elements together. Once it is recognized that patents and copyrights should be subject to limited terms, it becomes possible to transfer most of the legal principles from the physical to the intellectual realm. Far from being dead, a unified system of property rights for tangible and intangible assets could be brought to health by intelligent legislative and judicial action.

* James Parker Hall Distinguished Service Professor of Law, The University of Chicago; Peter and Kirsten Bedford Senior Fellow, The Hoover Institution; Visiting Professor, NYU Law School. My thanks to F. Scott Kieff, Randal Picker, Adam Samaha and Lior Strahilevitz, for helpful comments on an earlier draft; and to the members of the University of Chicago work-in-progress luncheon for helpful comments on an earlier draft. A shorter version of this Article was presented at the Conference on Intellectual Property at George Mason Law School in the spring of 2009. I should also like to thank Melissa B. Berger and Jeana Bisnar, NYU Law School Class of 2010, and David Goett, NYU Law School Class of 2011 , for excellent research assistance in preparing this Article. 


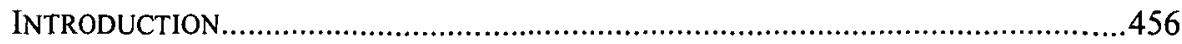

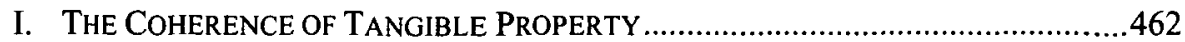

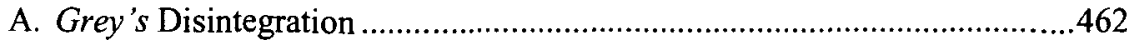

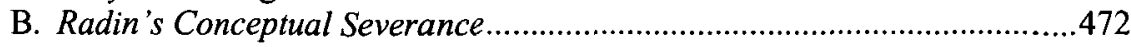

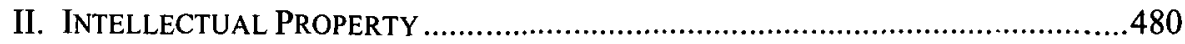

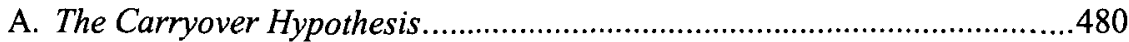

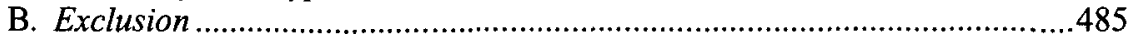

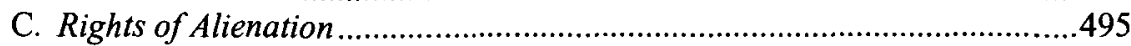

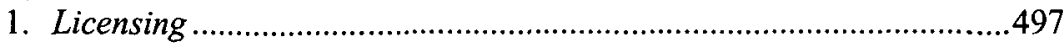

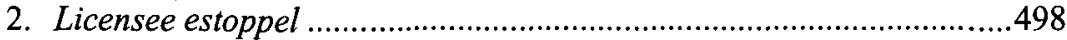

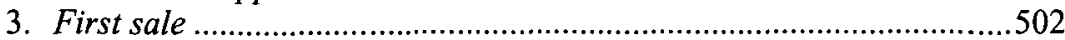

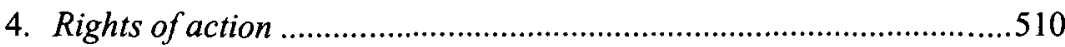

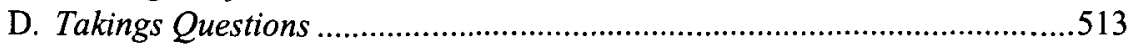

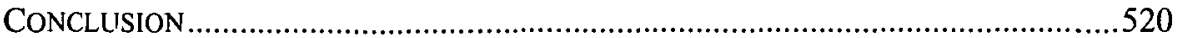

\section{INTRODUCTION}

The proper treatment of intellectual property, writ large, is the focal point of a high-stakes dispute that resonates both within and beyond legal circles. Roughly speaking, the protagonists over intellectual property fall into two broad camps. On the one side, there are those, like myself, who think intellectual property forms a coherent subset of a larger body of property law. Starting from this orientation, we constantly urge that the understandings of property law that have developed in connection with the traditional forms of tangible property can be carried over to intangible property even after the rise of modern technologies, such as the radio and the Internet. On the other side of the debate lie those who think that the rules of tangible property often provide little guidance for a sound system of intellectual property rights and should therefore be followed only with caution, if at all. The first side thinks that the law that is now in place can be improved by a sound adherence to first principles. Its detractors regard the system as moribund. The thesis of this Article is that it is too soon to write an obituary for an integrated system of tangible and intellectual property.

The dispute over the proper role of tangible property goes back to ancient times. The present disputes over intellectual property reflect its late arrival on the legal scene. But it would be a mistake to assume that this temporal gap prevents the unification of the two systems, each of which arose in a timely fashion when needed. The Romans, for example, developed an immensely sophisticated system of property to deal with land and chattels, and to a lesser extent water. ${ }^{1}$ But the conditions of technology were such that Rome never developed any law of copyright. People had to pay small fortunes to get others

1. For a good, though somewhat dated, overview, see BARRY NICHOLAS, AN INTRODUCTION TO ROMAN LAW (1962). 
to copy their manuscripts. Who needs protection against unauthorized copying, which is a boon to the original author? But as the costs of copying go down, the prospect of dissemination at a profit becomes real, and legal systems start to develop forms of copyright protection that echo, even if they do not precisely imitate, the constellation of property rights over tangible objects.

Similar arguments are applicable to patents. In ancient times, there was no organized system for the accumulation and organization of knowledge. There were no techniques for standardization or instrumentation. In this primitive state of technology, patents were of little value. But once measurements are standardized, and manufacture is possible on a mass production basis, the legal protection of inventions becomes a plausible social objective, which is far easier to implement if it can borrow freely from the preexisting systems of property rights for tangible assets. It is therefore no accident that the first systems of patent law emerged, but only on a localized basis, in Venice in 1474 in terms that anticipate the modern statutes in the field, ${ }^{2}$ and consistently expanded thereafter. ${ }^{3}$ Copyright has an even later start, dating from the mid1550 s. $^{4}$

Historically speaking, the evolution of both patents and copyrights did proceed by analogy to physical objects, notwithstanding the one huge difference that no form of intellectual property can be reduced to possession. That point is surely important given that the possession of a tangible thing makes it relatively easy for the individual owner (who is usually, but not always, in possession) to use self-help to defend what he owns. Yet a regime that relies solely on self-help to protect tangible property is subject to obvious forms of abuse, so that it must be backed by a neutral system of state force to make it work. Indeed, much of the early development of land law both in Roman and common law systems revolved about the ability of individuals to resort to the legal system to recover land, chattels, or animals that had been taken from them by force. ${ }^{5}$ The use of physical possession is not, of course, possible with intellectual property, which leads many modern writers to regard it as sui generis. They stress the limited value of analogies to the older bodies

2. See, e.g., Giulio Mandich, Venetian Patents (1450-1550), 30 J. Pat. Off. Soc'Y 166 (1948). The operative provision commands that "every person who shall build any new and ingenious device in this City, not previously made in our Commonwealth, shall give notice of it to the office of our General Welfare Board when it has been reduced to perfection so that it can be used and operated." Id. at 177. The text of the Venetian law is reproduced in Robert P. Merges, Peter S. Menell \& Mark A. Lemley, Intellectual Property in the NEW TECHNOLOGICAL AGE 106 (3d ed. 2003). The statute thus anticipates the novelty, nonobvious, and utility requirements of the modern law.

3. See MERGES ET AL., supra note 2, at 105-11 for more on the early history.

4. Id. at 320-22.

5. For the evolution of the English system of protection, see FREDERICK W. MAITLAND, ThE FoRMS OF ACTION AT COMMON LAW (1936); for the Roman system, see NiCHOLAS, supra note 1 , at $98-157$. 
of law, given that information has two attributes that are not present with physical property: "non-rivalrous competition" and "non-excludability." 6

This claim of separation is overstated. There is, of course, no question that these last two elements must be taken into account in fashioning a complete account of intellectual property. But the inability of an owner to take physical possession of what he owns does not make it impossible for one person to have rights of exclusive use and disposition of the property in question. It only means that a legal system has to become more mature before it can handle the greater administrative burdens. In my view, the general heritage of tangible property cannot be disregarded because of the evident differences in the two systems of property rights.

As I hope to show here, I believe that huge returns lie from systematizing intellectual property by analogy and extension to successful legal regimes elsewhere. By following rules of proven worth in other areas, each new articulation of property rights need not be a voyage into the unknown. Instead, it can avoid the pitfalls for new forms of property rights by incorporating the salient features of established regimes. That incorporation cannot be slavish, however, because the information that lies at the core of intellectual property exhibits characteristics that are not shared by physical assets. A physical asset can be retained or given away, in whole or in part. But information can be both retained and given away at the same time. Any agreement, for example, whereby a trade secret is shared pursuant to a confidentiality agreement involves the simultaneous transmission and retention of information-but only if the contractual arrangements are given strong protection, as they typically are. ${ }^{7}$ Similarly, the publication of information about a new invention or the creation of a literary work presents the same advantages. The owner of the work can realize gain from its publication to the world without forfeiting legal protection for the invention.

In all these regimes, exclusion takes on a different coloration than it does with real property, but it still seeks to maximize the gains from both the creation and dissemination of protected information. Figuring out how to trade off exclusive ownership that gives strong incentives for commercialization

6. Dugie Standeford, Intellectual Property Regime Stifles Science and Innovation, Nobel Laureates Say, INTELl. Prop. WATCH, July 7, 2008, http://www.ipwatch.org/weblog/index.php? $\mathrm{p}=1129$ (reporting on the lecture given by Joseph Stiglitz on July 5, 2008 entitled Who Owns Science?):

IP is often compared to physical property rights but knowledge is fundamentally different,

Stiglitz said. It is a public good with two attributes-" non-rivalrous competition" and nonexcludability-meaning it is difficult to prevent others from enjoying its benefits. That runs counter to IP regimes, which are worse than exclusion because they create monopoly power over knowledge that is often abused, he said.

7. See, e.g., Rockwell Graphic Sys., Inc. v. DEV Indus., Inc., 925 F.2d 174, 177 (7th Cir. 1991) (noting that wide dissemination of trade secrets under confidentiality agreements is necessary for their efficient exploitation). 
against the free but uncoordinated use of information left in the public domain offers the single greatest challenge to preserving the health of the law of copyrights and patents. ${ }^{8}$ As I shall argue, the single adoption of one adjustment, and one adjustment only, goes a very long way to ease the transformation from tangible to intangible property. Just use limited terms of exclusive rights, longer for copyrights than patents, to work the transformation from tangible property to these two vital forms of intellectual property. At that point, the remainder of the rules that deal with tangible property, namely those that concern exclusion, use, and disposition, can be carried over without difficulty. The same can be said about the limitations that are imposed on a system of real property, including those that deal with special privileges-think of the law of private and public necessity-that allow one person to use the property of another, and the antitrust limitations that restrict the ability of any holder of tangible property to coordinate its actions with others or to engage in unilateral practices that monopolize a given market. ${ }^{9}$

I have little doubt that this model captures much of the historical evolution of property rights, in both writings and inventions, as a conscious extension of the classical liberal conception of property that is associated with such writers as John Locke, ${ }^{10}$ William Blackstone, ${ }^{11}$ and Adam Smith. ${ }^{12}$ Just for the record, it is important to quote the single (though misleading) sentence of Blackstone that is commonly thought to capture this world view. Property refers to "that sole and despotic dominion which one man claims and exercises over the external things of the world, in total exclusion of the right of any other individual in the universe." 13

Few people actually read this excerpt in its immediate textual context, which shows that Blackstone was well aware of the functional justifications for property rights, even within his natural rights framework. ${ }^{14}$ This additional

8. For the consistent championship of this view, see F. Scott Kieff, Property Rights and Property Rules for Commercializing Inventions, 85 MINN. L. REV. 697 (2000); F. Scott Kieff \& Troy A. Paredes, The Basics Matter: At the Periphery of Intellectual Property, 73 GEO. WASH. L. REV. 174 (2004).

9. See, e.g., The Sherman Act, 15 U.S.C. $§ ~ 1-2$ (2006). For my discussion of the connection between section 1 , that deals with cooperative arrangements among parties on the same side of the market, and section 2, that deals with unilateral practices of a single firm, see Richard A. Epstein, Monopolization Follies: The Dangers of Structural Section 2 of the Sherman Act, 76 ANTITRUST L.J. 205 (2009).

10. John Locke, Second TREATISE OF Government (C.B. Macpherson ed., Hackett Publishing Co. 1980) (1690).

11. William Blackstone, Commentaries on the Laws of England (Oxford, Clarendon Press 1765).

12. Adam Smith, The Wealth of Nations (R.H. Campbell and A.S. Skinner eds., Liberty Classics 1981) (1776).

13. 2 BLACKSTONE, supra note 11 , at $* 2$.

14. The full passage reads:

There is nothing which so generally strikes the imagination, and engages the affections of 
material explains that the defense of ownership cannot depend on receiving it from a prior purchaser, because that only pushes the ultimate inquiry back one step. How does the initial purchaser acquire the property in question? If by purchase, then the mystery is put back yet one more step. If not, then the alternative justification for private property has to be articulated and explained.

On this critical question, Blackstone was no natural law fetishist, as he immediately turns to examine the two rival theories of the acquisition of original ownership. ${ }^{15}$ The first of these, which dates back to Roman times, ${ }^{16}$ is the theory of occupancy whereby the first possessor of property becomes its owner, without the consent of any other person, given the relationship between the person and the thing. The second theory finds that the universal (if implied) consent of all other individuals justifies the institution in libertarian terms. Both of these theories have their weaknesses. The former does not explain why other individuals are so bound by the unilateral action of the first possessor. The second uses implied consent as a deus ex machina that ignores the serious holdout problems that would arise if actual consent were required. Blackstone was not able to resolve the perceived conflict between these two theories, given the inadequacy of both, ${ }^{17}$ so he diplomatically moves on to other questions, trusting the reader to choose between them.

There is, however, a better way to make his case. In particular, two clues are found in these famous passages. The first is found in Locke's observation that "[i]f such [i.e. universal] consent as that was necessary, man had starved, notwithstanding the plenty God had given him."18 The second is found in Blackstone's pithy observation "[n]ecessity begat property."19 This last reference to necessity hammers home the holdout point to which Locke alludes. That necessity conception, moreover, should be taken quite literally to indicate that the judgment that one individual should be able to bind the rest of the world with respect to a given piece of land must be set in a larger context where all individuals are entitled to do the same. The privatization of property cannot be done by universal consent in light of the formidable transaction costs that block the way. But the overall social utility of the institution, which Blackstone so eloquently defended, justifies this limitation on the natural liberty of all

mankind, as the right of property; or that sole and despotic dominion which one man claims and exercises over the external things of the world, in total exclusion of the right of any other individual in the universe. And yet there are very few, that will give themselves the trouble to consider the original and foundation of this right. . . But, when law is to be considered not only as matter of practice, but also as a rational science, it cannot be improper or useless to examine more deeply the rudiments and grounds of these positive constitutions of society. Id.

15. Id. at $* 8-* 9$.

16. See G. INST. 2.66 (W.M. Gordon \& O.F. Robinson trans.); J. INST. 2.1.30.

17. 2 BLACKSTONE, supra note 11 , at $* 8$.

18. LOCKE, supra note $10, \S 28$.

19. 2 BLACKSTONE, supra note 11 , at $* 8$. 
individuals to move about as they see fit, backed by the power of the state to justify the origin of the institution on what are overtly consequentialist grounds. ${ }^{20}$ The social gains from the increased production of land are shared widely across the population.

The rules that Blackstone imperfectly defended have come under constant attack by modern theorists who, writing in a pessimistic tone, think that some richer and deeper account is needed to justify the institution of property in the modern world. ${ }^{21}$ Their skepticism carries over to the law of intellectual property. Once the discussion shifts to intellectual property, every author whom I shall criticize in this Article-Thomas Grey, ${ }^{22}$ Margaret Radin, ${ }^{23}$ and Peter Menell $^{24}$ - bases his or her critique of the modern law on a two-pronged attack on the soundness or adequacy of the classical liberal conception of property rights embodied in Blackstone's famous definition, usually by focusing on my writings. ${ }^{25}$ The first prong of the attack seeks to undermine the basic coherence of the classical liberal approach to property rights in its own home court, as it were, of land and chattels. The second disputes the ability to extend insights about tangible property to intellectual property, especially, but not solely, for patents and copyrights. Both of these disputes arise in two related contexts. The first of these involves the private disputes that take place between ordinary individuals. The second involves the ability of the government to either take (in the sense of occupy and use) property, on the one hand, or to regulate its use and disposition on the other.

On both these issues, I think that the multiple critics have pronounced a premature obituary for the integration thesis. The basic principles of property law are alive and well, and they are capable of reasonable extension to all forms of intellectual property. To make good this claim that property law is now in good shape, I conduct the overall analysis on a simple two-by-two grid.

20. For a fuller discussion of this point, see Richard A. Epstein, Liberty Versus Property?: Cracks in the Foundations of Property Law, 42 SAN DIEGo L. REV. 1, 15-19 (2005).

21. See, e.g., Lawrence C. Becker, Property Rights: Philosophic Foundations 24 (1977); Richard Schlatter, Private Property: The History of an Idea 130-31 (1951); Morris R. Cohen, Property and Sovereignty, 13 CoRNELL L.Q. 8, 15-16 (1927). I have long been a stout defender of the first possession principle. See Richard A. Epstein, Possession as the Root of Title, 13 GA. L. REV. 1221 (1979).

22. Thomas C. Grey, The Disintegration of Property, in PROPERTY: NOMOS XXII: Yearbook of the American SocietY for Political AND Legal PhILOSOPhy 69 (J. Roland Pennock \& John W. Chapman eds., 1980).

23. Margaret Jane Radin, The Liberal Conception of Property: Cross Currents in the Jurisprudence of Takings, 88 COLUM. L. REv. 1667, 1667-69 (1988).

24. Peter S. Menell, The Property Rights Movement's Embrace of Intellectual Property: True Love or Doomed Relationship?, 34 ECOLOGY L.Q. 713, 720-21 (2007).

25. Grey does so elsewhere, with gusto. See Thomas C. Grey, The Malthusian Constitution, 41 U. Miami L. Rev. 21 (1986). 
On one axis lie physical and intellectual property; on the other lie private and constitutional disputes. I think that most of the mischief in both the public and private law has its origins in these two attacks on the classical liberal approach. The purpose of this Article is to explain why that approach remains superior to its modern substitutes, notwithstanding the undoubted vehemence of the critics. Accordingly, Part I deals with the attack on traditional conceptions of property with respect to tangible assets. Part II then carries the analysis over to intellectual property. The similarity of the issues that are raised in the two contexts offers, I believe, ample evidence that the carryovers and analogies are not only desirable, but also unavoidable.

\section{The Coherence of TANGible Property}

\section{A. Grey's Disintegration}

The title of this essay makes conscious reference to Thomas Grey's influential 1980 article, The Disintegration of Property, the title of which offers a pithy summary of its basic theme. Grey's claim is that in the modern capitalist age, the notion of property has become so encrusted with barnacles that it offers little guidance to the major policy choices of the present day. "It seems fair to conclude," he writes, "from a glance at the range of current usages that the specialists who design and manipulate the legal structures of the advanced capitalist economies could easily do without using the term 'property' at all."26

There is no uncertainty as to what conception of property falls in Grey's crosshairs. Right after the quoted sentence, Grey takes aim at "classical liberal thought" as embodied in the work of Blackstone in his Commentaries, Kant in his discussion in The Metaphysics of Morals, and the natural rights provisions that are found in many of the early American state constitutions. ${ }^{27}$ Grey's argument is consciously painted in very broad strokes, but its gloomy theme is that the proliferation of the different forms of property holdings places undue stress on the basic conception of property rights. One of his clear motives is to explain why the confused status of property rights helps explain the low status that the United States Supreme Court gives to the constitutional protection of property under both the Takings and the Due Process Clauses of the Fifth and

26. Grey, supra note 22, at 73.

27. Id. (citing 2 Blackstone, supra note 11 , at *2; ImMANUel Kant, The Philosophy OF LAW 81-84 (W. Hastie trans., Edinburgh 1887)). For an example of an early constitution with provisions for natural rights, see MASS. CONST. art. I, annulled by MASS. CONST. art. CVI ("All men are born free and equal, and have certain natural, essential, and unalienable rights; among which may be reckoned the right of enjoying and defending their lives and liberties; that of acquiring, possessing, and protecting property; in fine, that of seeking and obtaining their safety and happiness."). 
Fourteenth Amendments. ${ }^{28}$ In carrying out this mission, he relies on the thenrecent work of Bruce Ackerman to support the view that the modern "scientific definitions" of property have displaced the commonsensical, but ultimately unsatisfactory, view that laymen take toward private property. ${ }^{29}$

One key challenge for this theory is to identify the set of stylized developments-neither Grey nor Ackerman do any close historical work-said to mark the demise of the classical liberal conception of property. Grey identifies the key shift in ordinary locution of native speakers. The traditional view of property spoke about the relationship of a person to a particular thing. In contrast, the "modern specialist" sees property as a "bundle of rights," which Grey regards as a more "shadowy" conception. ${ }^{30}$

That criticism misses the mark. The key advantage of the bundle of rights image is that it allows individuals to sell off bits and pieces of a thing to various persons. Well structured, these transactions in question can proceed with great rapidity and generate complex distributions of rights so that after a while it becomes quite difficult to give an authoritative answer to the question of who counts as the "owner" of any given thing subject to these divided interests. But that point does not matter so long as it is possible to keep track of the interests so created and render each party its due. This approach works well with the division of property into legal and equitable ownership, where the legal owner holds the property in trust for the equitable owner. ${ }^{31}$ And it explains how it is possible to carve out other property interests in land: life estates and remainder interests, both vested and contingent; mortgages; leases; easements and restrictive covenants. The division of interests in chattels is often more restricted, given their limited value and, in many instances, their limited expected rights. Yet in all cases, so long as the division of rights sums up to the initial whole, the utility of the parties is improved without harming any outsider.

Looking at the extensive range of divided interests is therefore an odd way to demonstrate the breakdown of the classical liberal system of property rights under the demands of modernity. Historically, the English doctrine of estates developed to accommodate multiple interests in a single plot of land. The Roman conception of ownership is commonly thought to be more absolute because it found no place for elaborate sets of future interests. The only division of beneficial ownership it allowed was between the usufruct-roughly

28. See U.S. CONST. amend. V; U.S. ConST. amend. XIV, $\S 1$.

29. Grey, supra note 22, at 69 n.l (citing BrUCe A. ACKERman, Private Property AND THE CONSTITUTION 97-100, 113-67 (1977)). My opposition to this position has been consistent. For my critique of Ackerman (not cited in Grey), see Richard A. Epstein, The Next Generation of Legal Scholarship?, 30 STAN. L. REV. 635 (1978) (reviewing ACKERMAN, supra).

30. Grey, supra note 22, at 69.

31. Id. at 69-70. 
an inalienable life estate in possession-and the "bare ownership," or what we should call the reversion. There were no multiple life estates, contingent remainders or executory interests. But that law did contain an elaborate law of servitudes, and a nascent law of leases and mortgages, so that it would be incorrect to claim that the system did not permit any division of property interests. ${ }^{32}$

Indeed, we can take the argument one step further. The ability to fragment property into multiple interests is not just a legal curiosity; it is an economic engine that generates new possibilities for gains from trade in the rights over a single asset. The obstacle to desirable fragmentation lies in the high transaction costs that it takes to create, record, and enforce these divided interests. ${ }^{33}$ In this regard, one reason to restrict the proliferation of interests in real property is because it complicates the ability of third persons who wish to acquire an interest in the asset to know the state of the title. The ability to extract gains from assets increases as the transaction costs of creating divided interests fall. The key to driving down transaction costs is the development and implementation of standard modes of doing business, which others can imitate and adopt as the case may be. Mortgages, for example, that have different substantive terms are hard to bundle in packages that can be resold in the market to diversify risk. But standard forms, when consistently used in originating new mortgages, allow for securitization to take place. Now assets can be purchased, sliced, and recombined far more easily than if each of them contained different sets of terms. To be sure, there are risks with this procedure, which include valuation risks when the elements within a given portfolio become too complex. And, of course, voluntary transactions in this market can fall prey to undesirable systems of regulation that encourage imprudent lending, as with the meltdown in the financial markets, owing to a toxic combination of easy-money policies, ${ }^{34}$ excessive subsidies for subprime mortgages, ${ }^{35}$ and unwise mark-to-market accounting rules. ${ }^{36}$

Conceptually, the constant pressure to divide property rights into smaller

32. For the various interests in real property, see NiCHOLAS, supra note 1, at 98-157.

33. See, of course, R. H. Coase, The Problem of Social Cost, 3 J.L. \& ECON. 1 (1960).

34. See, e.g., John B. TAYlor, GetTIng OfF TRACK: How Government ACTIONS AND INTERVENTIONS CAUSEd, Prolonged, AND WORSENED THE FinANCIAL CRISIS 11-14 (2009).

35. See, e.g., id.

36. On mark-to-market accounting, there is a vast literature. See, e.g., Franklin Allen \& Elena Carletti, Mark-to-Market Accounting and Liquidity Pricing, 45 J. ACCT. \& ECON. 358 (2008) (noting the cascades of mark-to-market accounting); Press Release, United States Securities and Exchange Commission, Congressionally Mandated Study Says Improve, Do Not Suspend, Fair Value Accounting Standards (Dec. 30, 2008), available at http://www.sec.gov/news/press/2008/2008-307.htm. For my views, see Richard A. Epstein \& M. Todd Henderson, Marking to Market: Can Accounting Rules Shake the Foundations of Capitalism? (Apr. 15, 2009) (unpublished manuscript), available at http://papers.ssm.com/abstract=1385382. 
elements means that it is no longer possible to represent private property as constituting one indivisible thing. It now becomes a set of interests in that one thing, each of which is entitled to as much protection as the whole from which it derives. Eric Claeys makes the instructive observation that, historically, the legal realists seized on the bundle of rights phraseology as a tool to weaken the protection that the law afforded to property rights. ${ }^{37}$ His argument is that once the law dumbs down property to some arbitrary assemblage of rights, it undermines the willingness of judges and legislators to protect it against forms of regulation that impose limitations on the private rights of use and disposition, always in, of course, the name of the public interest.

There is good reason to doubt Claeys's novel claim. ${ }^{38}$ No one can seriously dispute the rise of state regulation over land during much of the Twentieth Century. But it is far more likely that the Progressives who championed this move had deep misgivings about the private control of the means of production in a capitalist system. In earlier periods, however, the phrase "bundle of rights" was used by the champions of private property, not its detractors. This image dates back to Roman law, which assigns three attributes to absolute ownership-possession, use, and disposition-all of which were dutifully carried forward into Anglo-American law. ${ }^{39}$ Without question, the fragmentation of property interests had been well established long before the "high point" of classical liberalism to which Grey refers. ${ }^{40}$ Clearly, something is amiss, and Grey's thesis fails to capture it.

In responding to Grey's large claims, it is important to understand the missing piece of the puzzle, which relates to the fundamental legal constraints that order this multiplication of interests. The first of these has to do with the relationship of the owner of property to the rest of the world. The classical liberal conception did treat rights of possession, use, and disposition as its core components. The right of possession was exclusive to the owner; the right of use was not unlimited but was bounded by the law of trespass and nuisance; and the right of alienation was strongly protected but was also subject to complex limitations, some of which made sense, and others of which did not. ${ }^{41}$ The details of these points need not detain the reader, so long as the one overriding constraint remains well understood. No transfer of rights, either in whole or in part, should do anything to either increase or diminish the rights of

37. See Eric R. Claeys, Takings: An Appreciative Retrospective, 15 WM. \& MARY BILL RTS. J. 439, 447-51 (2006).

38. For my friendly rejoinder, see Richard A. Epstein, Taking Stock of Takings: An Author's Retrospective, 15 WM. \& MARY BILL RTS. J. 407, 417-18 (2006).

39. See, e.g., A.M. Honoré, Ownership, in OXFORD ESSAYS IN JURISPRUDENCE 113-17 (A.G. Guest ed., 1961).

40. Grey, supra note 22 , at 73.

41. For a longer discussion of my view, see Richard A. Epstein, Why Restrain Alienation?, 85 COLUM. L. REV. 970 (1985). 
the original owner against the rest of the world.

The arguments in favor of this view do not rest on any arid sense of formalism, but reflect deeply practical concerns. Start with the risk that the transfer of rights could increase claims against third parties. Any ability of an owner to increase his rights against third persons through transfer would encourage pointless transactions for strategic gain. A owns land subject to a covenant with B against its use as a supermarket. With the covenant in place, the land is worth $\$ 1000$ to $\mathrm{A}$ and only $\$ 800$ to $\mathrm{C}$, a prospective purchaser. Even if transactions costs were zero, the property would never be transferred if the covenant "ran" with the property, given its reduction in value in C's hands. ${ }^{42}$ But now assume that for some reason, the legal system routinely allowed $C$ to take the land free of the covenant that was structured to run with it. In those circumstances, the land is now worth $\$ 1400$ to $\mathrm{C}$, relative to $\$ 1000$ to $\mathrm{A}$. So it looks as though the covenant prevents a beneficial exchange.

This analysis of the transfer from $\mathrm{A}$ to $\mathrm{C}$ ignores, however, the position of $\mathrm{B}$, the holder of the covenant. If that covenant were worth $\$ 1000$ to $\mathrm{B}$, then the transfer reduces the total value of the system by $\$ 600$, as C's $\$ 400$ gain is dwarfed by B's $\$ 1000$ loss, even if transaction costs are zero. If, contrary to these assumptions, the gain to $C$ from building the grocery exceeds the losses to B from having it built, the right approach usually is for A to buy out the covenant in order to allow the subsequent transfer to C. And in some circumstances, condemnation for fair value might well be appropriate if the holdout problems become acute. ${ }^{43}$ But the one unacceptable approach is to allow voluntary transfers between $\mathrm{A}$ and $\mathrm{C}$ to defeat the rights of third parties. Just this insight, for example, lies behind the inflexible common law rule that assignees of contract rights take subject to all defenses that could be raised against the assignor. ${ }^{44}$ Otherwise, the legal system encourages useless transfers to defeat important defenses, such as those based on fraud in the inducement or the statute of limitations. The paramount economic role for this rule is so great that it is hard to accept any time-bound critique that finds value in the rule at the "high point" of classical liberalism but no value today. Property rules are not ephemeral. The risk of strategic behavior is a constant threat in any world populated with a substantial fraction of self-interested individuals-which

42. For the modern synthesis, see Restatement (ThIRD) OF Prop.: Servitudes (2000) (developing a unified approach for easements and restrictive covenants). For a general discussion of this topic, see Susan F. French, Toward A Modern Law of Servitudes: Reweaving the Ancient Strands, 55 S. CAL. L. Rev. 1261 (1982) (anticipating the Restatement position, of which she was the Chief Reporter); William B. Stoebuck, Running Covenants: An Analytical Primer, 52 WASH. L. REV. 861 (1977). The reference to the ancient strands is to the Roman doctrines, which indeed featured a uniform approach. See G. INST. 2.14 (W.M. Gordon \& O.F. Robinson trans.).

43. See, e.g., Pa. Coal Co. v. Mahon, 260 U.S. 393 (1922).

44. RestatEMENT (SECOND) OF CONTRACTS $§ 336$ (1981). 
means any world at all.

The same argument holds for the reciprocal proposition about the loss of rights against third parties. No transfer between $A$ and $B$ should ever allow $C$ to increase his rights against A or B. Once again, the simple economic logic on this position remains as powerful today as it was at the height of classical liberalism. It would be ruinous to voluntary transactions of interests in property if their sale resulted in the loss of rights against third persons. At this point, all gains from trade would be necessarily truncated because of the new liabilities imposed for the benefit of third parties.

Here are two examples of how this could work in the context of public regulation. First, the Jarvis-Gann Amendment ${ }^{45}$ imposes significant caps on the increases in real estate taxes that can be imposed on the owner of property, but only so long as he or she does not sell the property. ${ }^{46}$ The rapid rise in market values leads therefore to a real disconnect, such that the owner who does not sell pays taxes keyed to inflation but not to the scarcity value of the land. Assume for concreteness that these taxes are $\$ 5000$ per year, which capitalized over time, is equal, roughly speaking, to about $\$ 100,000$. The alienation of the property results in a recalibration of the base so that the buyer has to pay a tax of $\$ 12,500$, subject to the same protection against future increases. That works out, of course, to a new lien equal to 250 percent of the old one, or $\$ 250,000$. Hence, unless the value of the property (assuming transactions costs are zero) in the hands of the purchaser exceeds the value in the hands of the seller by more than $\$ 150,000$ (the $\$ 250,000$ less $\$ 100,000$ ), the transaction will not take place, with an overall social loss in efficiency.

To be sure, there may be many good reasons to cap the total level of real estate taxes to deal with the risks of big government. But Jarvis-Gann skews the operation of voluntary markets and thus ignores the fundamental premise that benefits and burdens of ownership should "ride through" to subsequent takers. The proper result thus ties taxation to the value of the real estate, regardless of who owns it, at which point the transfer neither increases nor decreases those obligations.

The second example arises in the takings context. One persistent question is whether various land use restrictions should be allowed through regulation without paying compensation. For these purposes, I shall bracket the inquiry of how that takings question should be decided in suits brought by a single owner, and insist only on this proposition: the state should not be able to impose additional restrictions on the subsequent taker of the land just because he or she has notice of the regulation prior to purchase. The transfer of property interest never increases the power of the state relative to its claims against the original

45. Cal. Const. art. XIIIA (enacted by Proposition 13 passed in 1978).

46. The proposition was upheld against constitutional challenge in Nordlinger v. Hahn, 505 U.S. 1 (1992). 
owner.

Here again the basic argument is this: there is no reason to discourage mutually beneficial transactions by validating, without compensation, regulation against the buyer that could not be imposed unilaterally on the seller. As well stated in the early decision Tulk $v$. Moxhay, the ancient doctrines of privity of contract and privity of estate hold that the buyer stands in the shoes of the seller as against the world. ${ }^{47}$ That formal doctrine thus ensures that these transfers do not result in a loss of entitlement.

The judicial acceptance of this position in constitutional contexts is, however, shaky. In the important decision of Palazzolo v. Rhode Island, ${ }^{48}$ the Supreme Court took the right categorical position that alienation of propertyin that case a forced distribution of a liquidated corporation to its sole shareholder, no less-did not increase or reduce the state's right to impose wetland regulation without compensation. That decision represents a very sound extension of a basic principle of private law into the public law, and shows, if demonstration is needed, the fundamental conceptual linkage between them, which also holds for intellectual property.

Nonetheless, good outcomes do not always remain settled. Two years later, in Tahoe-Sierra Preservation Council, Inc. v. Tahoe Regional Planning Agency, the Supreme Court retreated from this clear and sensible rule to a muddy declaration that notice of government action was one factor that a court could take into account in deciding whether the imposition of a regulation was a compensable event. ${ }^{49}$ This ostensible refinement gives us the worst of both worlds, as a certain and efficient rule gives way to an uncertain rule whose only function is to undermine gains from trade. Once again, uninformed claims of historical evolution should not be allowed to undermine a sound system of property rights. The basic proposition of classical liberal theory holds good across time and social circumstances.

The second part of the picture is every bit as important as the first. Grey gives a negative spin to the fragmentation of property interests through agreement. That is the force of the term "disintegration," as the opposite of integration - to make whole. It is therefore no surprise that the list of synonyms

47. See, e.g., Tulk v. Moxhay, (1848) 41 Eng. Rep. 1143, 1144 (Ch.) ("[I]t is now contended, not that the vendee could violate that contract [with the restrictive covenant], but that he might sell the piece of land, and that the purchaser from him may violate it without this Court having any power to interfere. If that were so, it would be impossible for an owner of land to sell part of it without incurring the risk of rendering what he retains worthless. ... Of course, the price would be affected by the covenant, and nothing could be more inequitable than that the original purchaser should be able to sell the property the next day for a greater price, in consideration of the assignee being allowed to escape from the liability which he had himself undertaken.").

48. 533 U.S. $606(2001)$.

49. 535 U.S. 302 (2002). 
in the Microsoft Word Thesaurus reads as follows: "meaning, breakdown; synonyms, breakdown, breakup, collapse, crumbling, dissolution, degeneration." Breakdown for its part leads to: "stop working, break, fail, collapse, go down, crash, go kaput and go wrong." Every connotation and every shade of meaning is negative.

The economics of the situation, however, reveal a very different picture once the second law of voluntary transfers is taken into account. All voluntary transactions generate gains for the parties in excess of the transaction costs to bring them about. Note the odd disjunction between an evaluative term, "disintegration," with ominous overtones, against an economic picture of increasing gains shared by all parties that conveys the exact opposite view. The rights of all third persons are strictly preserved by transactions that generate net gains to the trading parties. As a first approximation, this is a situation to be welcome.

The only question left, therefore is whether the preservation of rights (against both upward and downward movement) is consistent with the overall advancement of social welfare, which asks whether the subjective utility of the various parties increases as well. In general, this question also receives a positive answer. We know that voluntary transactions produce gains to all parties. We also know that the decline in transaction costs increases the number of persons to participate in transactions. And we also know that, on average, the increase in wealth to transacting parties will generate greater opportunities for trade to third persons, which enhances their welfare. Stated otherwise, the generation of gains produces positive externalities in the vast run of cases.

This proposition is not universal. There are some situations, for example, cartelization, where the sign of the externality turns systematically negative, which is why a carefully delimited version of the antitrust law may well make sense-both for tangible and intellectual property. ${ }^{50}$ But that modification of the basic property rights system is consistent with the classical liberal conception that always showed a consistent reluctance to enforce contracts that might be in restraint of trade..$^{51}$ It is, however, wholly misleading to take the great achievements of the legal system-accurate recordation, the statute of frauds ${ }^{52}$-as evidence that something is amiss with the property system, when the exact opposite is true. Unlike price control laws, for example, these formalities are not intended to reduce the security of transactions but to improve it. Any increase in the velocity of reliable and enforceable transactions, or in the ability to create divided interests in property, has positive

50. See infra at pp. $483-485$.

51. See, e.g., Mitchel v. Reynolds, (1711) 24 Eng. Rep. 347, 348 (Q.B.) (finding a covenant not to compete valid subject to limitations on duration, area, and scope of business).

52. 29 Car. 2, c. 3 (1677) (Eng.). 
consequences both for individual wealth and for social welfare.

It would, for example, be a serious mistake to assume that the disintegration that Grey speaks about is a sign of system malaise that parallels the creation of the anticommons in property, both tangible and intangible. ${ }^{53}$ The anticommons problem arises, if at all, when separate parties are not able to coordinate their activities, so that the actions of each operates as a blockade against the others. But the consensual division of rights is always structured in ways that facilitate, not frustrate, future levels of coordination. So long as the owners of each thread of a complex tapestry derives from a single owner, more fragmented property rights signals gains for trade, not institutional paralysis.

Grey's attack on the coherence of the property rights system is not confined to tangible property, but extends to other forms of property as well. Not surprisingly, he invokes, but does not discuss, patents and copyrights. Instead, in a fashion reminiscent of Charles Reich, ${ }^{54}$ his discussion focuses on decidedly traditional property and contract arrangements, including commercial paper, bank accounts, and insurance policies. ${ }^{55}$ Yet, once again, all of these arrangements long antedate the rise of the modern capitalist state, and at all times their legal uses and limitations have been well understood. Grey gives the instance of ordinary speak where we "deposit our money in the bank," 56 and cautions against thinking that we retain ownership of the discrete dollars in question, when what is done is to create a "set of abstract claims against an abstract legal institution." 57

The argument fails. Put aside the point that there is nothing abstract about a bank. The difference between deposits of a specific thing to be returned and the deposit of a fungible, where the return obligation required only the repayment

53. See Michael Heller, The Gridlock Economy: How Too Much Ownership Wrecks Markets, Stops InNovation, AND Costs Lives (2008); Michael A. Heller, The Tragedy of the Anticommons: Property in the Transition from Marx to Markets, 111 HARV. L. REV. 621 (1998). For its application to patents, see Michael A. Heller \& Rebecca S. Eisenberg, Can Patents Deter Innovation? The Anticommons in Biomedical Research, 280 SCIENCE 698 (1998). On average, I think that these concerns are overrated. See Richard A. Epstein \& Bruce N. Kuhlik, Is There a Biomedical Anticommons?, REG., Summer 2004, at 54; Richard A. Epstein, Takings, Commons, and Associations: Why the Telecommunications Act of 1996 Misfired, 22 YALE J. ON REG. 315, 334-35 (2005); see also F. Scott Kieff, On Coordinating Transactions in Intellectual Property: A Response to Smith's Delineating Entitlements in Information, 117 YALE L.J. POCKET PART 101, 106-08 (2007). The gist of the criticism of Heller and Eisenberg lies in the want of parallelism between the unenforceable and sub rosa entitlements doled out by bureaucrats and the binding licenses that IP owners create in their assets. Typically, no IP owner wants to keep a wasting asset on the shelf. In those cases where a patent is not exploited, the typical explanation is that the patentee holds substitute patents of greater commercial promise.

54. Charles A. Reich, The New Property, 73 Yale L.J. 733 (1964).

55. Grey, supra note 22, at 70-76.

56. Id. at 70 .

57. Id. 
of a thing of like kind, is as old as the Roman Law distinction between the wide range of bailments (of the specific res with an obligation to return) and mutuum (a specialized transaction in which ownership in some fungible was passed to the recipient who was obligated to return something of the same kind, without interest, down the road) ${ }^{58}$ These arrangements started with fungible materials like sugar, but were quickly and easily extended to money. But rightly understood, they are only fully accounted for by the two principles outlined above. As against the world, the ownership of the thing passes to the recipient in the contract of mutuum, so there is no split interest as in bailment cases. ${ }^{59}$ And for the latter, the Romans developed comprehensive rules to indicate who had the right to bring suit for the loss of the thing and what the obligations were that the holder of the right of action had toward his contracting party. ${ }^{60}$

So it is that divided ownership in land and chattels poses challenges to any legal system. But Grey was wrong to assert that the parties could not figure out who counted as the owner in these situations. Rather, they developed rules that allowed any designated party to sue on behalf of all persons that had an interest in the thing in order to simplify transaction costs. Thus, fundamental principles of trust law held that an outsider was bound and entitled to deal with the trustee, and thus did not have to concern himself with the complex division of interests behind the trust, which attached to the proceeds of any sale, once the trustee gave good title to the third party. ${ }^{61}$ Similarly, modern practice follows along the same line in complex syndication that designates a lead partner that is in charge of relationships with the rest of the world subject to a range of prespecified obligations, which could require consultation with fellow partners or limit its scope of action without the requisite approvals of other partners.

It is quite evident therefore that the supposed challenges to any modern legal system have been overcome by techniques of very old vintage. Quite simply, the solutions that were developed in Roman and early English periods are the ones that, with slight variations, are in use today. The basic rule here was, and remains, that the division of property into separate interests can

58. See NiCHOLAS, supra note 1, at 167-71.

59. For a simple discussion of the difference, see $i d$.

60. On the relationship between the positive and negative interests, see G. INST, 3.2033.207 (W.M. Gordon \& O.F. Robinson trans.).

61. For a discussion of the trust, see Law of Property Act, 1925, c. 20, $\S 1$-2 (Eng.) (dealing with the creation of equitable interests and protecting persons who take the legal title from the tenant for life in possession, even with knowledge of the equitable interests behind the trust). Also see Settled Land Act, 1925, c. 18, $\S 38$ (Eng.), allowing a tenant for life to sell the entire fee simple; and section 110 protecting third parties who deal with the tenant for life in his role as trustee. These legal reforms have not been adopted in the United States, but even so, the creation of legal life estates in land, for example, is quite rare, because of the attendant inconvenience. For the proposal to adopt the English system, see C. Dent Bostick, Loosening the Grip of the Dead Hand: Shall We Abolish Legal Future Interests in Land?, 32 VAND. L. REV. 1061, 1090-95 (1977). 
produce gains from specialization. The key relationship thus asks whether the gains from voluntary fragmentation exceed the added transactions costs of running the system. As these costs decline with recordation and more modern tracking devices, the complexity of property interests should increase without violating either of our two conditions, relating to the rest of the world and among the parties. Once again, the flexibility of the legal system produces no sign of disintegration. Grey did not examine the inner workings of classical legal institutions either at Roman or common law before concluding the classical liberal conceptions of property rights have outlived their usefulness. Rather, an understanding of the overall situation only shows their durability.

\section{B. Radin's Conceptual Severance}

Grey's critique of property rights on conceptual and sociological grounds does not stand alone in the literature. Another influential effort to pronounce a death sentence on traditional conceptions of property rights lines is Margaret Radin's provocative effort to whittle down the protection that the Takings Clause $^{62}$ supplies to the common law conceptions of private property. Her preferred tool of interment is her intriguing but misleading notion of "conceptual severance." 63 This term has as its implicit opposite a functional or economic severance. The use of the term "conceptual" is thus intended to discredit those, like myself, who do not draw any categorical distinction between physical takings, whereby the government occupies land, and regulatory takings, whereby the government limits the rights of owners to use and dispose of land, consistent, of course, with the basic common law restrictions on these two incidents of ownership. ${ }^{64}$ Once again the effort is to dismember the system, not to nurse it back to conceptual health.

Her critique neatly resonates with Grey, who also notes with some uneasiness that the Supreme Court in Penn Central Transportation Co. v. New York City ${ }^{65}$ resorted to "thing-like" conceptions to hold that the owner of the air rights over Penn Station was not entitled to compensation for the loss of their use. ${ }^{66}$ Clearly if the fragmentation of interest is given its due weight against the government, then, as Grey recognizes, the outcome of Penn Central

62. U.S. CONST. amend. V ("[N]or shall private property be taken for public use, without just compensation.").

63. See Radin, supra note 23 , at $1674-78$.

64. For the distinction, see Loretto v. Teleprompter Manhattan CATV Corp., 458 U.S. 419 (1982) (holding that per se liability exists only where a taking is physical).

65. 438 U.S. 104 (1978).

66. Grey, supra note 22 , at 72 . In fact, he gets it backwards. If the air rights were a separate thing, then compensation would have been owed for the total taking. But treating the parcel as a whole, Penn Central, 438 U.S. at 130-31 \& n.5, as the underlying thing, the air rights become a mere fraction of the whole for which compensation is not owed. 
"is difficult to rationalize in the terms of modern legal and economic theory." But there is no reason for surprise given that Justice Brennan (writing for the majority) was far more concerned with preserving state options to regulate land use in what he regarded as desirable ways than with developing a coherent theory of property rights. How he did this is worth some analysis because of the large role that Penn Central is assuming in intellectual property cases. Brennan's first move anticipates the Grey logic. He proclaims that the entire subject is so complex that no law-like proposition can govern the situation. Here, his target of opportunity was the account of the Takings Clause offered by Justice Black in Armstrong v. United States: "[T]he 'Fifth Amendment's guarantee ... [is] designed to bar Government from forcing some people alone to bear public burdens which, in all fairness and justice, should be borne by the public as a whole.",68

In the Armstrong case, that robust proposition cashed out by saying that the United States could not dissolve a materialman's lien imposed on one of its vessels by sailing out of state waters so that the lien would no longer attach. The repairs for the ship benefited the nation as a whole, not just the materialman. The effect of the government's maneuver was that the lienholder became a general creditor, entitled to just compensation, once the lien was invalidated. The government could not run, or sail, away from its obligations. It hardly matters that mortgage liens do not fit easily into the artificial dichotomy between physical and regulatory takings. What matters is the effort of the government to deflect its obligation on a single hapless party. In a case like Penn Central, Justice Black's proposition could also apply, where it cashes out along identical lines. Here too it does not matter that the restriction of the air rights does not fit easily into either the class of physical or regulatory takings. Rather, what is critical is that their owner is asked to sacrifice their use for the benefit of the public at large. It therefore should not have to bear that cost alone when the public at large enjoys the benefit of the increased light and open spaces. The unity of the basic proposition survives the difference in the specification of the underlying property rights. Its crisp articulation and decisive application is a sign of the good health of the legal system.

In Penn Central, however, Justice Brennan opted for disintegration, not clarity. At no point did he attempt to identify any critical difference between air rights and liens, even though he knew that both constituted property interests that were fully protected under state law. Instead, Brennan fled to a higher level of abstraction by insisting that the Supreme Court had proven incapable of developing any "set formula" to answer the takings question, leaving the field

67. Grey, supra note 22 , at 72.

68. Penn Central, 438 U.S. at 123 (quoting Armstrong v. United States, 364 U.S. 40, 49 (1960)). 
open to "ad hoc" formulations ${ }^{69}$-always a sign of incurable intellectual weakness. The upshot is his full version of the famous Penn Central test:

In engaging in these essentially ad hoc, factual inquiries, the Court's decisions have identified several factors that have particular significance. The economic impact of the regulation on the claimant and, particularly, the extent to which the regulation has interfered with distinct investment-backed expectations are, of course, relevant considerations. So, too, is the character of the governmental action. A "taking" may more readily be found when the interference with property can be characterized as a physical invasion by government than when interference arises from some public program adjusting the benefits and burdens of economic life to promote the common good. ${ }^{70}$

No longer does the Constitution protect private property. Now it protects "distinct investment-backed expectations." "11 In engineering this linguistic shift, Justice Brennan pays no attention to the simple fact that the separation of air from land rights takes place by ordinary conveyance, and as such represents yet another useful division of property, along with leases, mortgages, and freehold estates in land. In so doing, he shows no respect for the proposition that the division of property interest by voluntary transaction should neither increase nor decrease the obligations of government, which should have to pay for the loss of use rights that its regulation imposed.

This basic proposition puts a major crimp in the modernist efforts to denature the protection that the Takings Clause affords to private property by refusing to track in their constitutional analysis the permutations built in on the ground floor of any mature system of private property. Radin's notion of conceptual severance was introduced precisely to break the connection between public and private law. Her objective was to legitimate the long-line of Supreme Court decisions starting with Village of Euclid v. Ambler Realty Co. ${ }^{72}$ and running through Penn Central, which have refused in most, but not quite all cases, to award any compensation for loss of values from restrictions on use in the nature of restrictive covenants. ${ }^{73}$ Hence Radin states that a "conceptual severance"

consists of delineating a property interest consisting of just what the government action has removed from the owner, and then asserting that that particular whole thing has been permanently taken. Thus, this strategy hypothetically or conceptually "severs" from the whole bundle of rights just those strands that are interfered with by the regulation, and then hypothetically

69. Id. at 124 .

70. Id. (citations omitted).

71. Id. at $124,127$.

72. 272 U.S. 365 (1926); see Radin, supra note 23 , at 1673 \& n. 31 .

73. The exception is Lucas v. South Carolina Coastal Council, 505 U.S. 1003 (1992), which held that total deprivations that left no viable economic use were fully compensable under a per se rule, while lesser deprivations were compensable only under the mushy rules of the Penn Central decision. 
or conceptually construes those strands in the aggregate as a separate whole thing. 74

Radin adopted this approach to refute the views on takings and property rights that I took in my 1985 book, Takings. ${ }^{75}$ But it is worth noting that I never once resorted to this strategy to make my case against the Supreme Court's unwillingness to protect rights of use and disposition for parties who were allowed to remain in possession of land. No matter. Radin's larger effort was to attack my "naive conceptualism,"76 my "philosophical camelswallowing"77 in using "literalism or semantic reductionism in constitutional interpretation." 78 My mistake was to adopt an approach that allows courts to "mechanically decide" most individual cases, without engaging in any kind of "value inquiry"79 associated with any evolving sense of constitutional meaning. It is no surprise that she cites with approval the vehement attack that Thomas Grey wrote in 1986 about Takings, with the similar intention to prevent the carryover of a unified conception of private property from private to public law, given the immense limitations it imposes on the exercise of legislative power. ${ }^{80}$

In undertaking this task, both Grey and Radin clearly recognize that mine is not a marginal critique of the current legal order but part of a prolonged campaign to dislodge it from its current high judicial perch. But my campaign is not in defense of legal atomism. Rather, the analysis given above reveals the functional explanation for my position, which is, of course, to discourage various forms of strategic behavior by either private parties or government in the takings area.

To return to the Penn Central situation, it is descriptively incorrect to say that the separation of ground from air rights was done conceptually, or for that matter strategically, in order to make the government pay. The parties entered into a voluntary transaction that by design worked an actual severance of the two interests in accordance with state law, which was done in order to increase the total value of the parcel in its private hands, not to increase the odds of

74. Radin, supra note 23 , at 1676.

75. Richard A. EpStein, Takings: Private Property and the Power of Eminent DOMAIN (1985).

76. Radin, supra note 23 , at 1669.

77. Id. at $1669 \mathrm{n} .6$ (citing Grey, supra note 25 , with approval).

78. Id. at 1670 .

79. Id.

80. See Grey, supra note 25 , at 23 ("Takings belongs with the output of the constitutional lunatic fringe, the effusions of gold bugs, tax protestors, and gun-toting survivalists."). Radin's contribution to that symposium volume was Margaret Jane Radin, The Consequences of Conceptualism, 41 U. MIAMI L. REV. 239 (1986). For my contributions to that volume, see Richard A. Epstein, An Outline of Takings, 41 U. MIAMI L. REV. 3 (1986), and Richard A. Epstein, A Last Word on Eminent Domain, 41 U. MIAMI L. REv. 253 (1986). 
receiving compensation, or its amount, under the takings law. Put otherwise, the economic logic of this transaction does not depend on the decision of New York City to take or restrict the use of the air rights. The question of compensation should not turn therefore on which of these two terms, "take" or "restrict the use of," better describes what New York City did.

The factual point, however, is something of a detail, for there is every reason to afford full compensation for the loss of the air rights whether or not they had been severed from rights to the ground. In a well-functioning system, we do not want to either encourage or discourage transactions by improving or compromising the position of the owner of property. That result can only be achieved if compensability is resolved in the same way regardless of whether the air rights are retained by their original owner or conveyed to a third person. Under those circumstances the only transactions that will take place are those which are desirable from a social point of view-hardly the vision of a naive conceptualist.

Herein lies the rub. Which way should the parity run? Under the Supreme Court law (both in 1988 when Radin wrote and today), the fundamental and flawed structural distinction, already alluded to, is between a physical occupation for which compensation is owed no matter how small, and the regulation of use and disposition which is governed by the far more forgiving balancing tests of Penn Central, subject only to an exception (in ways that became crystal clear only in 1992 with Lucas $^{81}$ ) for those rare takings that result in a total loss of economic value from the property in question.

Unfortunately, these undefended compensation rules induce parties to engage in all sorts of games to increase compensation. ${ }^{82}$ The issue lurks in the well-known numerator/denominator problem to which Radin rightly refers. ${ }^{83}$ That conceptual tangle is solely an artifact of the current refusal. to develop a coherent theory for partial takings. That reintegration of property law can only be successfully completed if regulatory takings are treated as continuous with total takings. At that point, in both cases it becomes possible to defend this thesis: the more that the government takes, the more it pays. Unfortunately, the modern discontinuous conception holds precisely the opposite: the larger the numerator, relative to the denominator, the better the odds of receiving

81. Lucas v. S.C. Coastal Council, 505 U.S. 1003 (1992); see also supra text accompanying note 73 .

82. For my most recent attack on the current edifice, see RICHARD A. EPSTEIN, Supreme Neglect: How to Revive Constitutional Protection for Private Property (2008).

83. For a discussion, see Palazzolo v. Rhode Island, 533 U.S. 606, 631 (2001); Richard A. Epstein, Takings: Descent and Resurrection, 1987 SuP. CT. REV. 1, 16-17; Frank I. Michelman, Property, Utility, and Fairness: Comments on the Ethical Foundations of "Just Compensation" Law, 80 HARV. L. Rev. 1165, 1192 (1967). See generally John E. Fee, Unearthing the Denominator in Regulatory Takings Claims, 61 U. CHI. L. REV. 1535 (1994). 
compensation under the Takings Clause.

Why? Because the specifically tailored interest makes it easier to establish a claim that "the" idiosyncratic property has been completely extinguished and thus has no residual value, which precludes the possibility that it has some viable economic use. It was to forestall this maneuver that Justice Brennan held that the property was the entire block of land in which Penn Central had air rights. ${ }^{84}$ Now the retention of the building on the ground precluded a wipeout of the entire parcel when the air rights were taken. Given this legal framework, landowners have the strong incentive to opt for small units of property, ideally, which just cover the interests whose use is subject to regulation. And in some cases, they may seek, by conveyance, to create the desirable denominator. The state, of course, must develop rules that deny recovery whenever private owners attempt to game the present system.

Radin is right to condemn that form of strategic behavior by private individuals, but she should have also condemned the Supreme Court rules that sow the intellectual confusion that makes this wasteful game-playing worthwhile. The only way to avoid this charade is to have a rule that compensates for the loss of use rights to the extent of that loss, whether the two interests are united or severed. At this point, the present owner has all the right social incentives: sell the property, or an interest therein, when it is worth more to the buyer than it is to the seller; otherwise keep it. Forget the epithets "conceptual," "mechanical," and "naive." Ask instead what rule does a better job of policing the boundaries between the individual property owner and the state, when the proper object of both state confiscation and regulation is to improve overall value.

The first step in that healing process is to make sure that the individual owner is not left worse off as a consequence of the government action. If he is, government takings can be negative sum projects, as the state does not bear the full cost of its action. Requiring the payment of compensation reduces the likelihood that the state will condemn for transient reasons. After all, there must be some social gains that would induce participants in the political process to expend funds that reflect the private losses inflicted by government actions.

It is, however, insufficient from a social point of view just to block all negative sum projects. The second task therefore is to devise legal rules and institutions that maximize the gain from positive sum projects. ${ }^{85}$ In this regard, the key maneuver is to find some way to stabilize the surplus that is created from the same factional pressures that are everywhere at work in regulation settings. The key intuitive force behind the proportionate impact approach in Armstrong is that it achieves exactly that result without requiring a detailed

84. Penn Cent. Transp. Co. v. New York City, 438 U.S. 104, 130-31 (1978).

85. For a detailed account of how this works, see RichaRD A. EPSTEIN, BARGAINING WITH THE STATE 98-103 (1993). 
investigation of the gains and losses to each party. This rule requires that all parties subject to the government taking (including government regulation) receive benefits proportionate to their invested interests. It therefore precludes efforts by one landowner to hold out for a disproportionate share of the total gains. It would be inappropriate to allow inside payments where there is no disproportionate impact, but critical to allow them when one party is subject to adverse effects that are imposed on no others. At all points the intuitive conception of justice tracks a sound system of social welfare.

In the face of this strong theory, it is odd that Radin offers no functional justification for the current chaotic situation. Rather, she retreats to a "pragmatic" world-view that "essentially ad hoc, factual inquiries" should be used to resolve these cases in "all-things-considered intuitive weighing." ${ }^{86}$ But ask these questions: will this approach reduce decision costs-no; will it add to predictability-no; will it force public officials to take into account all gains and losses in making their decisions-no, again. But Radin (like Grey) has another agenda. She fears that a rigorous conceptual and functional account of private property will pose a mortal threat to the constitutionality of most progressive and New Deal legislation. ${ }^{87}$ But it is not sufficient to fear a result. It is critical to explain why it does not follow from the texture and structure of the Constitution.

So, once again, the conclusion seems clear: two rules are sufficient to shape all property transactions. No voluntary transaction between two or more parties should either trench on the legal rights of third persons or allow third persons to trench on their rights. I can think of no change in social circumstances or technological advances that requires deviation from these principles. All the flexibility that is needed to deal with airplane overflights, the electromagnetic spectrum and, as will become clear, intellectual property can be accommodated by a system that allows takings for just compensation to complement the universe of voluntary transactions.

The one key element to make this system work is the notion of implicit in kind compensation, which only means that the compensation that is tendered to one person could be in either cash or kind, including rights received under regulation. ${ }^{88}$ This principle is an effort to incorporate into the context of a general theory of takings law the well-cited Holmesian notion that endorses general rules that create an "average reciprocity of advantage." ${ }^{\prime 89}$ Within the zoning system, for example, height restrictions on one parcel of land could be compensated for by parallel restrictions on the nearby parcels, so long as the value of both parcels increases in consequence of the regulation. That one

86. Radin, supra note 23, at 1680 (quoting Penn Central, 438 U.S. at 124).

87. Id. at 1682 .

88. For articulation, see EPSTEIN, supra note 75, at 195-215.

89. Pa. Coal Co. v. Mahon, 260 U.S. 393, 415 (1922). 
principle allows one to take a coherent approach to the legal transformation of property rights that allows for the realization of genuine social improvements, such as overflight rights, pooling of oil and gas interests, wildlife, and, of course, the defense of intellectual property. ${ }^{90}$

Clearly, this conceptual framework is strong enough to deal with changed circumstances. It also has the great advantage of weeding a large number of small claims out of the system, even though they meet the definitions of a prima facie taking. ${ }^{91}$ Thus, for example, the general rule announced in First English Evangelical Lutheran Church of Glendale v. County of Los Angeles, that temporary takings were compensable unless they were involved with the "normal" delays in processing permits. ${ }^{92}$ That exception makes sense because it filters the short delays to which all landowners are subject. But at the same time, it affords no protection to the endless set of delays that are part and parcel of many land use sagas before the Supreme Court, which are not remotely balanced out by the smaller losses imposed on others. Thus, in the marathon situation in Tahoe-Sierra Preservation Council, Inc. v. Tahoe Regional Planning Agency, Chief Justice Rehnquist's dissent was surely correct when it noted that the short periods of time-typically under six months-that were allowed by statute for administrative delay were appropriate, even though marathon hearings were not. ${ }^{93}$

Nor does this system necessarily mean that important environmental interests cannot be vindicated without payment of explicit compensation. Thus, in Tahoe-Sierra no one should dispute that the eutrophication of Lake Tahoe's pure blue waters counts as the kind of harm that the state could prevent without having to compensate abutting landowners. But the failure to tie the police power to the law of nuisance meant that local politics dominated over sound water management. The incumbent landowners, whose finished driveways contributed so much to the pollution of Lake Tahoe, were effectively immunized from any legal sanction, so that their past malfeasances were left uncorrected. Yet at the same time the onerous restrictions imposed on newcomers prevented the development of houses on the land, which on a per square foot basis are far more valuable than asphalt driveways.

The costs of this error are severe. The misguided protection of finished development over future development always gives local governments no incentive to undo past errors when they can force the brunt of inefficient preservation errors on outsiders who have not yet built. Make it clear that

90. For application of this principle, see EPSTEIN, supra note 82, at 58-63 (oil and gas), 57-60 (overflights), 63-65 (wildlife), 158-62 (intellectual property).

91. See Gary Lawson \& Guy Seidman, Taking Notes: Subpoenas and Just Compensation, 66 U. CHI. L. REV. 1081 (1999) (discussing why subpoenas do not generate claims for compensation).

92. 482 U.S. 304,321 (1987).

93. 535 U.S. 302 , 351-54 (2002) (Rehnquist, C.J., dissenting). 
existing owners are as responsible as future ones for the condition of the lake so that they must compensate anyone who is restricted to covering over less land than existing owners have, and the driveways will quickly be torn out. ${ }^{94}$ There is, in sum, no reason to resort to a crazy-quilt pattern of decision-making under the fashionable banner of pragmatism when a single coherent theory is capable of taking into account all relevant factors and answering all questions in a principled fashion. The use of terms like "conceptual severance" just conceals the want of a coherent theory of property rights. It still takes a theory to beat a theory. Grey and Radin have no theory to displace the classical liberal position they seek to refute. It emerges from these assaults in fine shape.

\section{INTELLECTUAL PROPERTY}

\section{A. The Carryover Hypothesis}

Now that the general framework on property rights has been established, this Part of the Article asks how its principles do, and should, influence the growth of intellectual property law.

One possible response to this challenge is to conclude that copyrights and patents should not be recognized at all. The argument here is not as farfetched as it sounds. It insists that the standard moves in the property lexicon should apply to this area, and these do not allow for any person to obtain exclusive possession of either an invention or a writing, given the intangible nature of both. To be sure, people can have possession of a particular instantiation of an invention, or of a piece of stone, parchment, or paper that contains a literary work. And it is possible for the owner of these to use contract to secure that other individuals gain access to this material only on the assumption of confidentiality. ${ }^{95}$ Yet both of these traditional techniques, alone and in tandem, could not generate two of the most powerful forms of intellectual property. On the other hand, the protection of trademarks would face rather brighter prospects because the exclusive control of the mark is widely understood as a means to prevent the use of a mark that "is likely to cause confusion, or to cause mistake, or to deceive." 96

The obvious source of difficulty therefore is with patents and copyrights. Indeed the strongest formulation of the objection is not indifferent to the

94. For a discussion of the various permutations of this theme, see Richard A. Epstein, The Ebbs and Flows in Takings Law: Reflections on the Lake Tahoe Case, 1 CATO SuP. CT. REV. 5(2002).

95. See supra text accompanying note 7.

96. The Lanham Act, 15 U.S.C. § 1114(1)(a) (2006), shows how the libertarian concem with fraud plays a key role in the organization of one area of intellectual property law. 
statutory protection afforded to patents and copyrights. Rather it regards these two statutory forms of property, with some evidently ad hoc features, as the quintessential antiproperty whose creation necessarily interferes with the basic rights of speech and action that all individuals enjoy in the state of nature. Thus, Tom Bell has written: "More pointedly, copyright and patent protection contradicts Locke's justification of property. By invoking state power, a copyright or patent owner can impose prior restraint, fines, imprisonment, and confiscation on those engaged in peaceful expression and the quiet enjoyment of their tangible property." from the skeptical turn of mind exhibited by Grey and Radin. Rather, he places such great stock in the Lockean view-that property must be acquired by taking a physical object that is unowned in the state of nature - that he believes that common law possessory rights block the state creation of property rights in writings and inventions. ${ }^{98}$

I think that this ingenious libertarian attack on copyrights and patents fails because it operates in too narrow a conceptual framework. The only question it asks is whether a system of state-created property rights in writings and inventions is consistent with the libertarian conception of property rights, which gives all individuals exclusive ownership over their own persons and exclusive property rights in those things that they acquire by taking possession, or by purchase from a prior possessor. But the more comprehensive analysis treats the libertarian position only as the initial baseline for analysis - one that is far preferable to Hobbes' war-of-all-against-all in the state of nature.

This case for the Lockean rules on property rights is overtly utilitarian. In the long run, property rights make everyone better off than they would have been in a world with no limits on liberty of action and, in consequence, offered no security in one's own person or possessions. The libertarian position thus is best understood as a Pareto improvement ${ }^{99}$ over the state of nature. But once we can devise legal rules that generate one improvement, it is necessary to ask whether it is possible to generate additional changes that can improve the overall situation relative to this (second) Lockean baseline. ${ }^{100}$ On this point,

97. Tom W. Bell, Indelicate Imbalancing in Copyright and Patent Law, in CoPY Fights: The Future of Intellectual Property IN THE INFORMation Age 1, 4 (Adam Thierer \& Wayne Crews eds., 2002) [hereinafter COPY FIGHTS]. In a similar vein, see Tom G. Palmer, Are Patents and Copyrights Morally Justified? The Philosophy of Property Rights and Ideal Objects, in CopY FIGHTS, supra, at 43, 43-44.

98. Bell, supra note 97 , at 3.

99. Vilfredo Pareto, Manual of Political Economy 261 (Ann S. Schwier \& Alfred N. Page eds., Ann S. Schwier trans., Augustus M. Kelley 1971) (1927) (defining a class of changes in economic allocation, now referred to as Pareto improvements, that make at least one individual better off, and none worse off, than those individuals were ex ante).

100. See Epstein, supra note 20; see also text accompanying note 20. For the larger philosophical framework, see Richard A. Epstein, The Not So Minimum Content of Natural Law, 25 OXFORD J. LEGAL STUD. 219 (2005). 
there is a strong empirical case that offering limited protection to creators through patents and copyrights will introduce innovation that will redound to the benefit of the outsiders in the long run. This strategy concedes the impairment of Lockean rights, only to insist that the transformation is justified because all persons are left better off in a regime that creates patents and copyrights. Stated otherwise, the benefits that all individuals receive from the robust systems of patent and copyrights supply implicit-in-kind compensation that offsets, and more, the loss of individual liberty from the restraint of speech and productive activities.

The key question of system design, therefore, asks what configuration of patents and copyrights will maximize the net gains over the libertarian formulation. The best approach is to determine how few deviations from the traditional views of property in tangibles need to be made in order to develop a sensible system for copyrights and patents. In my view, the obvious place to start is with the duration of these interests, given that the distinctive feature of information is its capacity to be both shared and retained at the same time. That universal and invariant characteristic of information suggests that the infinite duration of ownership, which works so well for land and chattels, is a poor first approximation for constructing a nascent law of copyrights and patents.

With tangible objects, it is of course possible to adopt a rule that limits possession to some fixed period of years, or for the life of the initial possessor. But note what happens with either of those configurations. The first negative effect is that it becomes difficult to construct or maintain improvements whose useful life coincides with the expected duration of the interest. If the improvement is not durable enough, an economic opportunity is lost. If the improvement lasts too long, there is a gift to the next possessor of the property. The situation is no better when we look to alienation, for the uncertainty in the duration of the term creates genuine ambiguities. It is for this reason that the English system eventually banned legal life estates in land, putting them behind a trust. And for the same reason, they are almost never created in the United States, even in the absence of legal impediment. Leases survive because they offer additional certainty in duration and often include clauses that deal with the treatment of improvements at the expiration of the lease, which help ease the transition between owners.

Yet, what is gained for the inconvenience of state-imposed limited terms? Precisely nothing. Once the land reverts to the state of nature, someone else will seek to claim it by occupation, only to be faced by the same temporal limitations that handicapped the actions of the original party in possession. There is, in short, no way that the expiration of the limit expands the class of individuals who can make simultaneous use of the property. It therefore follows that no system in which ownership is acquired through initial occupation contains any temporal limitation on the duration of the estate. Quite simply, none should. All divisions of interest should come by contracts that bind the 
parties, and when appropriate, their successors in title.

The tradeoffs are different with respect to intellectual property. The problems of alienation and transition at the expiration of the deal remain, although possibly in less acute form. But the social gains from the expiration of the copyright or invention are large because that expiration allows an extensive nonrivalrous use of the writing or invention to take place immediately, once these works are cast into the public domain. The constitutional compromise that recognizes the power of the United States to grant patents and copyrights with a limited life of protection works to split the difference between the two interests. $^{101}$ It first gives incentives for production (including commercialization); thereafter, opportunities for widespread dissemination at zero price in the public domain.

In dealing with this issue, we have to be concerned not only with the artificial truncation of the patent and copyright terms, but also with the converse situation where the duration of a patent or copyright is extended after it has been created. It is a large mistake (indeed a taking of private property) for the state to shorten by decree the period of an existing copyright or patent once it has been granted. By the same token, it is an improper transfer from the public space to extend existing patents and copyrights without a public benefit in return. As I have argued elsewhere, the implicit converse to the Takings Clause is the (conceptual) Givings Clause, "nor shall public property be given for private use, without just compensation," which is an assault on giveaways of all kinds of interest, tangible or intangible, present or future. ${ }^{103}$ And so there is abundant reason to attack ferociously the decision in the Copyright Term Extension Act to give longer terms to holders of existing copyrights, as I have done since its passage. ${ }^{104}$

Once, however, an alteration is made for that difference, it becomes less likely that we can identify any additional functional reason to reject the other pillars of the system of real and personal property dealing with exclusivity, use, and disposition. In particular, the rules for infringement could be patterned on the rules for trespass and conversion, which are well-developed for physical

101. U.S. CONST. art. I, $\S 8, \mathrm{cl} .8$ ("To promote the Progress of Science and useful Arts, by securing for limited Times to Authors and Inventors the exclusive Right to their respective Writings and Discoveries."). Needless to say, the harder question is just how long, for which the answer is always shorter for patents than copyrights.

102. See sources cited supra note 8.

103. For discussion, see Richard A. Epstein, The Public Trust Doctrine, 7 CATo J. 411, 419 (1987).

104. Sonny Bono Copyright Term Extension Act, Pub. L. No. 105-298, 112 Stat. 2827 (1998), sustained in Eldred v. Ashcroft, 537 U.S. 186 (2003). I criticize the statute in Richard A. Epstein, Why Libertarians Shouldn't Be (Too) Skeptical About Intellectual Property 1, 10 (Progress \& Freedom Found. Progress on Point Paper Series, Paper No. 13.4, 2006), available at http://ssrn.com/abstract $=981779$ (defending modern intellectual property on empirical grounds). 
assets. Accordingly, in my preferred system, the scope of pattern coverage should cover the full range of inventions and writing. More specifically, in the patent area, the broad reading that is given to the phrase "any new and useful process, machine, manufacturer, or composition of matter, or any new and useful improvement thereof," 105 should be given the reading that it received in Diamond v. Chakrabarty to cover "anything under the sun" that results from human labor and imagination, ${ }^{106}$ and that rule should be maintained without differentiation between business method patents and others. ${ }^{107}$ On this issue too there is a close resemblance between physical and intellectual property, as ideas, natural laws, and natural phenomenon take the place of rivers, oceans, and beaches as the dominant form of common property.

Once the scope of the property right is established, it is necessary to determine what actions constitute breach. In this context, infringementcoming within the fringe- is the patent equivalent for physical invasions. For an infringement, the basis of liability should be strict on the one hand, and the remedy of choice should be an injunction that allows the owner to block the infringement. This property-rights regime could be backed up by a system of damages, which would cover compensation for losses from previous infringements and supply an additional deterrent against future infringement. Similarly, the same rules that apply to dispositions, broadly conceived to include sales, licenses, mortgages, assignments of all sorts, and descriptions of land and chattels, could carry over to copyrights and patents. If we can have sales and licenses of the former, then so too of the latter. Additionally, the same principles of antitrust law, whether they deal with cartelization or unilateral practices, could carry over to patent and copyright owners, just as they do to owners of tangible property. And finally, the same rules that govern the governmental taking and regulation of tangible forms of property should work as well with the taking or regulation of patents and copyrights.

These transformations are less critical for trademarks and trade secrets, both of which better comport with the libertarian model of property. ${ }^{108}$ One evident sign of this is that in neither case is there any functional reason to impose an arbitrary limit on the duration of the interest. Since trademarks only have value insofar as they refer to the origin of some good, putting them into the public domain effectively strips them of their value. Likewise, since the origins of trade secrets are private creations that may be shared under

105. 35 U.S.C. $\S 101(2006)$.

106. 447 U.S. 303,309 (1980).

107. See In re Bilski, 545 F.3d 943 (Fed. Cir. 2008), cert. granted sub nom. Bilski v. Doll, 129 S. Ct. 2735 (2009). Bilski abrogated State Street Bank \& Trust Co. v. Signature Financial Group, Inc., 149 F.3d 1368 (Fed. Cir. 1998), and In re Alappat, 33 F.3d 1526 (Fed. Cir. 1994), both of which afforded broader protection to business-method patents.

108. For my views, see Richard A. Epstein, Intellectual Property: Old Boundaries and New Frontiers, 76 IND. L.J. 803 (2001). 
confidentiality agreements, there is no reason to limit trade secrets' duration either, especially since the holder of the trade secret can never preclude the independent creation of the same invention by others.

It is necessary, however, to identify a regrettable ambiguity in this approach. My implicit assumption thus far is that the law of copyright and patents can borrow from a sound body of classical liberal principles governing tangible property. But all too often, the modern law is in disarray on critical topics, in part because of the formless pragmatism of influential writers like Grey and Radin. At present, the rules governing real and personal property are sound in some areas but suspect in others. Thus, in general, the owner of real property has strong remedies of injunction to block the entrance of any other person onto his property, and to remove encroachments that might be found there. ${ }^{109}$ Yet by the same token, the California Supreme Court in Intel Corp. $v$. Hamidi ${ }^{110}$ recently analogized actions for trespass in cyberspace to those for trespass to chattels, concluding that an owner could use self-help to repel the invader but could not obtain injunctive relief from the court in the absence of tangible harm hampering the operation of the server. Unauthorized use of another's property, by those who can maneuver around blocks and filters, is now permissible in cyberspace, at least in one state.

So the real challenge is to see the extent to which we can find errors in outcomes when a sound set of classical liberal principles, subject to the duration limitation, do not carry over to intellectual property. But it is equally important not to mess up one branch of law in order to correct for mistakes that have been made in other areas. Accordingly, I shall now turn in greater detail to three areas, exclusion, alienation (with its antitrust overtones), and takings, to show the strength of the carryover thesis.

\section{B. Exclusion}

Now that the out-and-out libertarian skeptics of intellectual property, such

109. On encroachment, see Geragosian v. Union Realty Co., 193 N.E. 726, 728 (Mass. 1935) ("The general rule is that the owner of land is entitled to an injunction for the removal of trespassing structures.").

110. 71 P.3d 296 (Cal. 2003). Much of the scholarship regarding this case turns on the extent to which servers should be analogized to chattels or real property. See id. at 309. An attack on the real property analogies is mounted in Dan Hunter, Cyberspace as Place and the Tragedy of the Digital Anticommons, 91 CAL. L. REv. 441 (2003), which, published prior to the California Supreme Court's decision in Hamidi, criticizes the lower court decision in favor of the defendant, Intel. For criticism of the California Supreme Court decision, see Richard A. Epstein, Intel v. Hamidi: The Role of Self-Help in Cyberspace?, 1 J.L. ECON. \& PoL'y 147 (2005); David McGowan, The Trespass Trouble and the Metaphor Muddle, 1 J.L. ECON. \& POL'Y 109 (2005). I wrote an amicus curiae brief for Intel in the California Supreme Court. Brief for Cal. Employment Law Council et al. as Amici Curiae Supporting Respondent, Hamidi, 71 P.3d 296 (No. S103781) (on file with the Stanford Law Review). 
as Palmer and Bell, have not carried the day, the question remains of how the carryover across the various property fields should work. Exclusion is the obvious place to begin because it is a central component of any system of private property. Indeed, the right to exclusive possession and use is the only element of the traditional bundle of property rights that receives full-fledged constitutional protection under the Takings Clause. ${ }^{11}$ The rights of use and disposition, which are part of the traditional trilogy of property rights, are subject to various forms of regulation that can effectively eliminate most of the value from the asset in question. ${ }^{112}$ For the moment, I do not want to defend the stronger view that all three elements in the traditional bundle of rights should receive the same level of protection under both common and constitutional law. ${ }^{113}$

Immediately, there is one oft-noted and inescapable difference between the two realms. The sharp boundary lines in physical space cannot be duplicated with intellectual property. In particular, claim description for patents involves delicate questions of exclusion and inclusion. One clear requirement in this regard involves the elusive test of non-obviousness, where the statutory test holds that a patent may not be obtained "if the differences between the subject matter sought to be patented and the prior art are such that the subject matter as a whole would have been obvious at the time the invention was made to a person having ordinary skill in the art to which said subject matter pertains."114 The basic point of this provision is that the patent protection should not be given to persons whose new variations add little or nothing to the existing stock of knowledge. In dealing with this question, the most recent Supreme Court pronouncement rejects the so-called "teaching, suggestion, or motivation" test as the sole means of denying the incremental advance. ${ }^{115}$ While fuzzy boundaries exist in real property cases, they obviously loom larger in intellectual property cases. The sensible social objective is to pick the test that

111. See, e.g., Kaiser Aetna v. United States, 444 U.S. 164 (1979). Kaiser Aetna involves some real complications because it did not involve an outright transfer from the private owner to the United States. It only required that the private marina open its waters to general navigation, which in effect demoted private property into a commons to which the original owner had full access. But this point should only influence the amount of compensation, not the existence of a taking.

112. See, e.g., Penn Cent. Transp. Co. v. New York City, 438 U.S. 104 (1978).

113. See EPSTEIN, supra note 75 , at 57-62.

114. 35 U.S.C. $\S 103(a)(2006)$.

115. KSR Int'l Co. v. Teleflex Inc., 550 U.S. 398, 407 (2007). In my view, that older test has real virtues insofar as it limits the use of subjective testimony to deny after the fact the nature of the innovation. On the facts of the case, I think that the district court was correct to deny patentability for a supposed invention that involved merely the realignment of known elements. See Teleflex Inc. v. KSR Int'l Co., 298 F. Supp. 2d 581, 587-588 (E.D. Mich. 2003). The reversal of its decision in the Federal Circuit, Teleflex Inc. v. KSR International Co., 119 F. App'x 282 (Fed. Cir. 2005), opened up the way for the Supreme Court decision. 
minimizes the sum of decision and error costs.

The fuzzy boundaries inherent in the description of patent claims invite, of course, new entrants to game the system by coming as close to the original patent description without crossing the line. If those new inventions were made without a detailed knowledge of the relevant invention space, it would be easy in a strict liability regime to show some solicitude to those who came close to the line that they did not cross. But all patent claims are constructed by professionals who have an intimate knowledge of the relevant space. Accordingly, to counteract this conscious gamesmanship, courts have rightly resorted to the doctrine of equivalents, which asks whether the defendant's invention is close enough to the literal description of the patentee's invention that it should be held to violate the patent's scope. ${ }^{116}$ The analogous but less difficult doctrine in copyright is whether the defendant's work is derivative of the plaintiff's because, although it does not borrow specific words or pictures, it works on closely identified themes. ${ }^{117}$ These difficulties, too, cannot be evaded so long as patents and copyrights provide any legal protection to inventions and writings. No matter what remedy is chosen, the question has to be answered, even if infringements of IP rights are necessarily less precisely defined than those for physical property. Nor is it easy to set up any default presumptions on how to resolve close cases, for any rule that is targeted to control the opportunism of infringers can give too much rein to the parallel opportunism of copyright or patent holders. And the converse result happens if the default provision is reversed to favor the entitlement holders.

Yet once the infringement is determined, the question is which remedy should apply: damages or an injunction. On this issue it is possible to be more definitive. The present state of play on this question is shaped by the critical decision of the United States Supreme Court in eBay Inc. v. MercExchange, L.L.C. ${ }^{118}$ At issue in the case was a choice between two rules for granting an injunction. The Federal Circuit applied "the general rule that courts will issue permanent injunctions against patent infringement. absent exceptional circumstances." 119 In its stead, the Supreme Court adopted the traditional

116. The relevant provision reads, but only with difficulty, as follows:

An element in a claim for a combination may be expressed as a means or step for performing a specified function without the recital of structure, material, or acts in support thereof, and such claim shall be construed to cover the corresponding structure, material, or acts described in the specification and equivalents thereof.

35 U.S.C. $\S 112$, ๆ 6 (2000). For recent Supreme Court application, see Festo Corp. v. Shoketsu Kinzoku Kogyo Kabushiki Co., 535 U.S. 722 (2002); Warner-Jenkinson Co. v. Hilton Davis Chemical Co., 520 U.S. 17 (1997).

117. E.g., Nichols v. Universal Pictures Corp., 45 F.2d 119 (2d Cir. 1930) (denying action against the authors of The Cohens and the Kellys for infringement of Abie's Irish Rose).

118. 547 U.S. $388(2006)$.

119. MercExchange, L.L.C. v. eBay, Inc., 401 F.3d 1323, 1339 (Fed. Cir. 2005). 
principles of equity, which made the issuance of an injunction turn on four related factors:

(1) that [the plaintiff] has suffered an irreparable injury; (2) that remedies available at law, such as monetary damages, are inadequate to compensate for that injury; (3) that, considering the balance of hardships between the plaintiff and defendant, a remedy in equity is warranted; and (4) that the public interest would not be disserved by a permanent injunction. ${ }^{12}$

One way to approach this problem is to ask which rule mirrors the rule for injunctive relief in physical injury cases. What makes that inquiry difficult is that both rules have some sort of a common law (here used in the sense that includes remedies that courts of equity issue in private disputes) pedigree, so that it is not always easy to distinguish between them. But putting aside questions of verbal nuance, the unmistakable difference between the two tests is that injunctive relief is easier to obtain under the rule announced in the Federal Circuit than under the Supreme Court rule.

The Federal Circuit rule starts with a strong presumption in favor of the injunctive relief. In one sense, that preference follows from the definition of property as the right to exclude. In the patent context, this basic element of property theory has long been held "to provide for an exclusive right to inventors to make, use and vend their inventions," leading to the creation of a "complete monopoly" for which injunctive relief is required as a matter of course. ${ }^{121}$ Damages thus become the backup remedy, since they are needed to compensate for past losses, where injunctive relief is futile. ${ }^{122}$ But the Patent Act also provides, not all that helpfully, that courts may "grant injunctions in accordance with the principles of equity to prevent the violation of any right secured by patent, on such terms as the court deems reasonable." 123

The major textual question is, how did the Federal Circuit move that rule to a conclusion that grants the injunction save on exceptional circumstances? The best answer to that is that the importance of an injunction with respect to future harms is that it keeps open the channels for voluntary exchange, by making it impossible for individuals to circumvent the basic rules of property law for their short-term private advantage. On this issue, the encroachment cases involving real property offer a useful example. Normally, a defendant whose building encroaches on the plaintiff's property is required to remove the encroachment at great expense, even when the value of the plaintiff's underlying land is small. The rule is virtually automatic when the infringement is deliberate, and strict even when it is not. Two reasons explain this set of rules. The first is that only the injunction prevents the exercise of a private

120. eBay, 547 U.S. at 391.

121. Cont'l Paper Bag Co. v. E. Paper Bag Co., 210 U.S. 405, 423 (1908).

122. 35 U.S.C. $\S 284(2006)$.

123. Id. $\S 283$. 
power of eminent domain. The second is that only the injunction prevents the circumvention of voluntary transactions that work to the benefit of both sides.

The case for an injunction is, if anything, stronger in those contexts where it is hard to value the profits or royalties lost in consequence of the defendant's violation. And it is commonly understood that damages are often speculative at best when complex technologies are involved. The injunction avoids a regime of compulsory licenses at the insistence of the infringer that would on average undercompensate the owners for their investment and make it impossible for patent holders to develop coherent licensing strategies that target select licenses under complex licensing deals. ${ }^{124}$ It is therefore better to keep the train on the tracks than to allow one party to deviate from the straight and narrow for private advantage.

The rule in effect represents a sound categorical judgment that the harms from infringement are irreparable in the sense that no damage award will do as well to honor for the basic property right as the equitable injunction. The basic considerations here do not turn on the specifics of any particular invention, so the strong presumption is in effect a way to avoid the high administrative and error costs associated with case-by-case judgments. On this general view, the play in the joints comes from the last part of the statutory provision, which allows the injunction to be granted on such terms as the court deems reasonable. That caveat is best read to let the court take into account the difficult transitions that often accompany the issuance of an injunction. For example, it may make sense not to demand that a defendant recall at great expense items that have already been sold to distributors; or it may be desirable to delay the injunction to allow the defendant to work around the patent or negotiate a license with the plaintiff, paying some form of interim damages for the privilege. These kinds of ad hoc adjustments are certainly part of the equitable principles governing land, as it is often common for courts to delay the effect of an injunction to allow a defendant to tidy up.

Within this framework, what counts as an "exceptional" circumstance that defeats injunctive relief? Here, the relevant cases fall into two separate classes. The first of these deals with laches ${ }^{125}$ and estoppel, ${ }^{126}$ that is, with conditions

124. Evidence on this question is hard to acquire and evaluate. For one effort, see Colleen Chien, Cheap Drugs at What Price to Innovation: Does the Compulsory Licensing of Pharmaceuticals Hurt Innovation?, 18 BERKELEY TECH. L.J. 853 (2003) (reporting that compulsory licensing did not have a discernible negative effect on innovation). But Chien's qualifications are in a sense more important than her results, which held only with respect to "licenses that were either unpredictable or did not affect important markets." Id. at 857. Relax these two assumptions and there is no reason to think that the results will not flip over. Indeed, in her one case where these two conditions did not entirely hold, she did detect some decline in $R \& D$, which suggests that larger impositions could have greater results, depending of course on the anticipated discount through these licensing arrangements.

125. Odetics, Inc. v. Storage Tech. Corp., 185 F.3d 1259 (Fed. Cir. 1999) (laches).

126. Wang Labs. v. Mitsubishi Elecs. Am., 103 F.3d 1571 (Fed. Cir. 1997) (allowing 
whereby the plaintiff's own conduct establishes the grounds for denying or limiting injunctive relief. These cases do not pose a mortal, or even serious, threat to the dominance of voluntary transactions, because it always lies within the power of the plaintiff to avoid the delay or misrepresentation that becomes the source of the defendant's claim.

The more difficult cases for the Federal Circuit rule involve the risk of economic extortion when a minor patent can derail a major enterprise. The most vivid situation is a case where a defendant's complex product has thousands of different components of which only one is covered by the plaintiff's patent. The nightmare example is the holder of a single small patent who wants to shut down the latest Microsoft word-processing program. The fear here is that the price demanded to waive injunctive relief far exceeds the value that the patentee could have obtained if it had licensed the product to the defendant before the defendant developed its new product.

This consideration carries a good deal of weight, at least in these extreme cases. Yet it is instructive that there is no decided case in the Federal Circuit that granted an injunction under such extreme conditions, eBay included. It would be as if the person who owned a square foot of land under a large factory could require the entire factory to be ripped down because of the trespass. Quite simply, as the size of the overall venture looms ever larger relative to the size of the plaintiff's input, the injunctive relief falls by the wayside. It would have been quite possible for the Supreme Court to have affirmed the Federal Circuit rule by announcing that these cases of massively disparate stakes were inappropriate for injunctive relief, at least without allowing some additional time to correct the particular error by designing around the minor component. The traditional framework appears to be able to handle the case that is calculated to cause it the greatest embarrassment. The carryover from the land use cases to the intellectual property cases looks well-nigh complete.

Yet what about the four-part equitable test in $e B a y$ that appears to make the choice of remedy in each and every patent case a fact-intensive inquiry? The new formulation does not mark any real advance in doctrine. Indeed, it heralds some retreat from the previous, narrower test. The first two components of the four-fold test, "irreparable injury" and "inadequate" damages, are mirror images of each other. It is not possible to think of any important case where the injury may be regarded as irreparable when the damages are adequate. What is missing, however, from this reformulation is the background presumption that serious institutional damage follows whenever a defendant is able to circumvent the voluntary market by creating what is in essence a compulsory license whose terms are set by a court, not the parties.

Nor do the last two factors help advance the ball. The third factor on

course of conduct to establish estoppel). For the parallel doctrine in real estate transactions, see Holbrook v. Taylor, 532 S.W.2d 763 (Ky. 1976). 
relative hardship carries with it little or no content if it invites the court in routine cases to make some guess as to the magnitude of the economic dislocations that each side suffers. How, for example, could it not be a case of real hardship for the plaintiff who suffers irreparable harm if an injunction is denied? The only way in which the term seems to resonate is in the situation mentioned above: the defendant has a complex device with many elements, of which only one tiny component infringes the plaintiff's patent. At that point, however, we are back to the one narrow exception that should be grafted onto the "exceptional circumstances" test.

So this leaves the fourth element, which involves the impact of the grant or denial of the injunction on the public at large. In order for this factor to carry real weight, it is necessary to show that there will be cases in which the injunction seems justified between the parties but will be denied because of its adverse effects on third persons. It is possible to think of extreme situations where this might be true - the widespread use of a patented wonder drug that offers the last line of defense against a deadly plague, for example. Yet once the dispute reaches that level, it is likely that the government would interfere under a doctrine of public necessity, much as it does when it rips down buildings in order to prevent fires from destroying the community at large. ${ }^{127}$ But short of these extreme cases, it is difficult to imagine circumstances in which the public interest does not require the creation and maintenance of a secure system of property rights to spur the innovation and commercialization of new technologies.

In the end, therefore, the irreparable harm test seems to be the touchstone for the inquiry, and the dispute over injunctive relief seems to turn on the choice between rules that are applied on a categorical or a case-by-case basis. Taken as a whole, the post-eBay decisions show a decided, but by no means complete, tendency to revert back to class-based rules. To see why, it is useful to return to the basic categorization of injunctive relief cases. In this regard, a useful point of departure is a short statement by the academic defenders of the traditional equitable principles in their brief to the United States Supreme Court. That brief, of which Mark Lemley was the principal author, held that courts "should grant injunctions to patent owners who participate in the market, whether by selling the patented invention, exclusively licensing it to someone else who sells it, or selling a product not covered by the patent but which competes with the infringing product." ${ }^{128}$ This pithy statement identifies three

127. Mayor of N.Y. v. Lord, 18 Wend. 126 (N.Y. 1837).

128. Brief of Fifty-Two Intellectual Property Professors as Amici Curiae Supporting Petitioners at 9, eBay, Inc. v. MercExchange, L.L.C., 547 U.S. 388 (2006) (No. 05-130). For a response, see Brief of Various Law \& Economics Professors as Amici Curiae Supporting Respondent, eBay, 547 U.S. 388 (No. 05-130) [hereinafter eBay Amicus Brief Supporting Respondent], which I coauthored with F. Scott Kieff and R. Polk Wagner. David Teece, an economist at the University of California, Berkeley, also aided in the drafting of the brief. 
situations to apply the per se rule within the context of traditional equitable rules: the plaintiff practices the patent, the plaintiff issues an exclusive license for the patent, and the plaintiff warehouses the patented technology in order to make some substitute technology, patented or unpatented. It is critical to understand both the normative uses and limitations of this principle, and its reception in the lower courts in the post-eBay cases.

On practicing the patent, the post-eBay cases offer solid support for the proposition that the injunction should issue against a defendant whose infringing product is in direct competition with the plaintiff's. ${ }^{129}$ That conclusion is often accompanied by dire judicial admonitions to the infringer. ${ }^{130}$ The level of protection so offered does not give the practicing patentee protection in all cases. But there are few instances of patent infringement where the parties are not in direct competition, at least if the party who practices the patent is in a position to license it to someone else who is.

That possibility in turn gives rise to the second key element, which is the exclusive licensing of a patent. In principle, the exclusive license resembles a sale insofar as the full beneficial use of the patent now lies in the patentee. The rule here is not dissimilar to the rule that asks about the sale or lease of a structure for tax or business purposes. If the useful life of a building is twentyfive years, a lease for thirty years leaves the original owner with a reversionary interest that has no value. The transaction is therefore better treated as a sale of the asset, so that the depreciation deduction must be taken by the erstwhile lessee rather than the erstwhile property owner. Since patents have finite useful lives, it simply makes no sense to conceive of a sale that exceeds the duration of the patent life.

The exclusive license differs from the sale, however, in that there is no fixed price for the patent use, as patent royalties are calibrated to the intensity of use. In addition, exclusive licenses are complex documents that often allow the patentee or licensee to terminate the arrangement for cause, after the passage of time, and the like. The key point to understand, however, is that these exclusive licenses are yet another illustration of the key proposition that two parties are allowed to divide rights between them in whatever fashion they see fit so long as they do not trench on the entitlements of any third parties. Allowing the exclusive licensee to sue for the injunction thus preserves the remedial status quo against outsiders.

129. See TruePosition, Inc. v. Andrew Corp., 568 F. Supp. $2 d 500$ (D. Del. 2008) (injunction against direct competitor); TiVo, Inc. v. Echostar Commc'ns Corp., 446 F. Supp. 2d 664 (E.D. Tex. 2006) (same).

130. See, e.g., 3M Innovative Props. Co. v. Avery Dennison Corp., No. 01-1781, 2006 U.S. Dist. LEXIS 70263, at *5-*6 (D. Minn. Sept. 25, 2006) ("One who elects to build a business on a product found to infringe cannot be heard to complain if an injunction against continuing infringement destroys the business so elected." (quoting Windsurfing Int'l v. AMF, Inc., 782 F.2d 995, 1003 (Fed. Cir. 1986))). 
There is, unfortunately, some legal authority to the effect that only the exclusive licensee is entitled to seek injunctive relief on the ground that any injury to the licensor is not "irreparable." 131 That limitation makes no sense because it creates a situation where a license to two or more parties reduces their (combined) remedial rights against an outsider. One of the signs of an efficient contract is the allocation of entitlements between the parties that maximizes their joint wealth. If the licensor has a level of expertise in litigation that its various licensees cannot match-perhaps because he owns a portfolio of patents - the litigation system will work better if the licensor controls litigation.

A still more serious limitation of this formulation is that it appears to imply that injunctive relief is a chancy proposition whenever a patentee issues multiple nonexclusive licenses. In this situation, the dangers are acute because it is highly unlikely that one of a large number of licensees would have sufficient incentive to enjoin the outside infringer. He bears all the cost of the change and gets only a fraction of the benefits. When nonexclusive licenses arise with tangible property, the licensor normally controls the litigation precisely because he is in the best position to internalize the largest fraction of the gains. If that action is not allowed, there is a real danger that the entire consensual system of licenses will unravel. The dutiful licensee is at a competitive disadvantage against the willful infringer, and thus has every incentive to join the ranks of willful patent infringers. In a two-party situation, someone could make the (incorrect) argument that the costs of litigation for damages are not all that greater than the costs of negotiating a complex licensing agreement. But when there are tens or hundreds of licensees, the negotiation costs, once standardized, increase slowly, while the litigation costs most assuredly do not, as each defendant presents its own special problems that start with service of process and extend through final judgment. Virtually every sensible collective operation allows a party at the center to control litigation for the group. The restriction of injunctive relief to exclusive licensees works a dramatic reduction in the effectiveness of the patent system for which there is no analogy for licenses to use tangible forms of property, and no discernible efficiency justification. The make-or-license decision should not be skewed by making the strong remedy dependent on choosing one form of business transaction. There is no reason to tilt the willingness to license, or the choice of licensees, by the selective availability of injunctive relief. Whether a patentee has one patent or a thousand in its portfolio, the choice of legal relief should never depend on how a patentee chooses to exploit his invention.

In sum, it looks as though any careful examination of the equities in the post-eBay world should collapse back into the initial presumption in favor of injunctive relief. In all the cases stated, that presumption should remain. The case of the tiny patent who exercises the exorbitant holdup does need some

131. See supra at pp. 487-492 for a discussion of eBay's four-part equitable test. 
attention at the margins, but it should never be the tail that wags the patent dog. Nothing in the traditional principles of equity requires that radical revision of the right to exclude that $e B a y$ seems to invite.

The position here tracks, again, the analysis of tangible property. As indicated earlier, the proper approach treats the limited patent term as irrelevant to the debate over the choice remedies. On this question, the common law approach to encroachment cases is especially relevant. This position is defended at length in a brief that I submitted with Scott Kieff and Polk Wagner. ${ }^{132}$ The key point is this: the use of the remedy that requires the wrongdoer to rip down its own structures looks inefficient from the ex post point of view. What gain is there in knocking down a skyscraper to return a couple of inches of land to the owner? But the ex post inefficiency has to be weighed against the ex ante advantage, which is that this rule reduces the willingness of potential encroachers to circumvent the property rights system by taking first and paying damages later. ${ }^{133}$

This defense of the Federal Circuit rule provoked a sharp response from Peter Menell, of the University of California, Berkeley, ${ }^{134}$ who mistakenly saw in our contention a reversion to some mystical Blackstone model that treats all property rights as "perpetual, exclusive, and inviolate" 135 - Menell's ill-chosen words and not mine. All three of these terms are overstated. As noted earlier, it is correct to subject the property rights in both patents and copyrights to limited terms. Indeed, on previous occasions-never cited by Menell-I cautioned against the unthinking transfer of the Blackstone model of property to patents and copyrights. ${ }^{136}$ But once the temporal adjustment is made, the rules on exclusion work, for in fact the boundary conditions on land have themselves never been treated as absolute and inviolate either. I have already mentioned rules on laches, estoppel, and disproportionate impact. In addition, it is appropriate to take note of the rules surrounding private necessity and public necessity cases at common law. ${ }^{137}$ The law of nuisance also contains a liveand-let-live rule that allows for small reciprocal harms to go uncompensated and imposes obligations of lateral support for the land of neighbors. All of

132. eBay Amicus Brief Supporting Respondent, supra note 128.

133. See, e.g., Voda v. Cordis Corp., 536 F.3d 1311 (Fed. Cir. 2008).

134. The full exchange was printed in Regulation. See Peter S. Menell, Intellectual Property and the Property Rights Movement, REG., Fall 2007, at 36 [hereinafter Menell, Property Rights Movement]; Richard A. Epstein, The Property Rights Movement and Intellectual Property: A Response to Peter Menell, REG., Winter 2008, at 58; Peter S. Menell, Intellectual Property and the Law of Land: A Reply to Richard Epstein, REG., Winter 2008, at 64; Richard A. Epstein, A Final Response to Menell, REG., Spring 2008, at 2.

135. Menell, Property Rights Movement, supra note 134, at 38.

136. See Epstein, supra note 108, at 804-06; see also Epstein, supra note 104, at 6.

137. See, e.g., Vincent v. Lake Erie Transp. Co., 124 N.W. 221 (Minn. 1910). 
these small adjustments improve the value of land for all others. Finally, the eminent domain power should remain for takings of public use, especially when assembly problems block voluntary transfers. ${ }^{138}$ The clear moral here is that the only way to see the carryover between land law and intellectual property is to offer an accurate explication of the former, which Menell does not provide.

\section{Rights of Alienation}

The next major question deals with limitations on the sale, licensing, and assignment of intellectual property. In dealing with tangible property, the distinction between land and chattels matters because the ideal of free alienation is more closely achieved with real property than for chattels. With land, at one time various legal doctrines restricted the use of servitudes, but modern developments in this area have removed most of the legal impediments against alienation, thereby facilitating the creation of complex planned-unit developments and condominiums. ${ }^{139}$ But the situation is far less clear with respect to chattels, where the general rule is that restrictive covenants do not run in the same fashion that they do for land.

The role of this disjunction between different forms of property was flagged in perceptive form as early as 1928 by Zechariah Chafee, who asked the fundamental question of the extent to which equitable servitudes ran with chattels. ${ }^{140}$ In a real sense, Chafee adumbrated the position that I have adopted here. His first instinct was to assume the soundness of the basic rule of Tulk $v$. Moxhay, ${ }^{141}$ whereby negative servitudes ran against all persons who had notice of their terms. In that decision, The Lord Chancellor, Lord Cottenham, said quite sensibly that if these covenants did not run with the land against persons who had notice of their existence, "it would be impossible for an owner of land to sell part of it without incurring the risk of rendering what he retains worthless." ${ }^{142}$ The clear implication of this position is that there may well be less alienation of real property if the covenants are not enforced than if they

138. On the use of eminent domain to acquire property from one private party to be transferred to another in the name of economic development, see Kelo v. City of New London, 545 U.S. 469 (2005) (recognizing economic development as a potentially valid "public use" for purposes of the Fifth Amendment's Takings Clause).

139. See, e.g., Neponsit Prop. Owners' Ass'n v. Emigrant Indus. Sav. Bank, 15 N.E.2d 793 (N.Y. 1938) (allowing a property owners' association to enforce a restrictive covenant against a bank that acquired title by judicial sale).

140. Zechariah Chafee, Jr., Equitable Servitudes on Chattels, 41 HARv. L. REv. 945 (1928) [hereinafter Chafee, Servitudes on Chattels]. For a reprise, see Zechariah Chafee, Jr., The Music Goes Round and Round: Equitable Servitudes and Chattels, 69 HARV. L. REV. 1250 (1956).

141. Tulk v. Moxhay, (1848) 41 Eng. Rep. 1143 (Ch.), also discussed supra note 47.

142. Id. at 1144 . 
are. Nor did he see any inconvenience from the rule:

Of course, the price would be affected by the covenant, and nothing could be more inequitable than that the original purchaser should be able to sell the property the next day for a greater price, in consideration of the assignee being allowed to escape from the liability which he had himself undertaken. ${ }^{143}$

The question that Chafee posed for himself was whether there was any reason to displace this basic model in the case of chattels. His discussion quickly turned to many cases dealing with the intersection between antitrust and patent issues. On the larger methodological question, he took this sensible position, lamenting in particular the logic of Justice Hughes in Dr. Miles Medical Co. v. John D. Park \& Sons Co. ${ }^{144}$ for its inability to offer

any reason for a distinction between land and chattels sufficient to offset the reasons for permitting the creation of equitable interests in both types of property which are afforded by the decisions on trusts and specific performance. There may, of course, be specific objections to particular restrictions on chattels, such as price maintenance and tying contracts, which must be considered on their merits; but such a discriminating treatment is very different from a wholesale rejection of equitable servitudes on chattels on the ground that there is some fundamental and eternal difference between personal and real property. ${ }^{145}$

Consistent with his general message, Chafee then devotes an extensive but inconclusive effort to weighing the advantages of first the resale price maintenance rule, ${ }^{146}$ and thereafter the rule on territorial restrictions for intrabrand competition. ${ }^{147}$ His initial effort was to see if these territorial restrictions have the kind of negative effect on the retained interest of the original owner that spurred the use of the restricted covenant in Tulk. ${ }^{148}$ After satisfying himself that they did not, he turns to more economic arguments that address in an oblique fashion the risks of free riding of one retailer on the efforts of another, which these vertical restraints are designed to counteract. ${ }^{149}$ In general, Chafee concludes that the case has not been made to deviate from Tulk.

This early interaction between the formal rules on servitudes and the more concrete concern with economic arrangements carries over to the present day. There is no doubt that the older tradition, which is reluctant to enforce restraints on alienation, even against strangers who take "with knowledge," continues to

143. Id.

144. 220 U.S. 373 (1911), overruled by Leegin Creative Leather Prods., Inc. v. PSKS, Inc., 551 U.S. 877 (2007).

145. Chafee, Servitudes on Chattels, supra note 140, at 984.

146. Id. at $987-95$.

147. Id. at $995-98$.

148. Id. at $985-86$

149. Id. at $988-89$. 
operate today, even in contexts as compelling as the land use regime in Tulk. The older rule prohibiting restraints on alienation can create immense difficulties in the distribution of software if the assignee of the original purchaser is to make more intensive use of the program than the assignor or to evade restrictions on consequential damages. ${ }^{150}$ Rules like the "first sale" doctrine in copyright law show the same dogged refusal to accept contractual restrictions on the resale of copyrighted materials. ${ }^{151}$

Moving on, there are a number of antitrust decisions dealing with unilateral practices that lead to the excessive imposition of liability, a situation that has been much improved with the latest generation of Supreme Court decisions. ${ }^{152}$ And finally, as noted, the takings law has evolved in a most unfortunate direction in the Penn Central case. ${ }^{153}$ These discrepancies matter as to how current bodies of law governing tangible forms of property carry over to intellectual property. Quite simply, as a descriptive matter, the strongest objection to the carryover approach is often that it relies on subpar rules for land and chattels to set the framework for intellectual property rules. As a normative matter, however, these difficulties do not register. On this approach, the first order of business is to construct the ideal set of rules for land and chattels and see the extent to which these rules survive in other contexts, whether cyberspace, as in Hamidi, ${ }^{154}$ or intellectual property, which is our primary concern here.

\section{Licensing}

Owners of property are normally entitled under current law to dispose of it as they see fit or to convey it to whomever they so please, which is as it should be. These new owners are in turn entitled to relicense what they have received to third persons, so long as they do not violate the terms or conditions of the

150. See, e.g., ProCD, Inc. v. Zeidenberg, 908 F. Supp. 640 (W.D. Wis. 1996) (holding a "shrinkwrap" license, which indicated that conditions on use were contained within the product packaging, to be unenforceable, thereby permitting the software purchaser to exploit the copyrighted contents without restriction), rev'd and remanded, 86 F.3d 1447 (7th Cir. 1996). For my comments on the case, see Richard A. Epstein, ProCD v. Zeidenberg: Do Doctrine and Function Mix?, in CONTRACTs StORIEs 94 (Douglas G. Baird ed., 2007).

151. See, e.g., 17 U.S.C. $\S 109$ (a) (2006) ("[T]he owner of a particular copy or phonorecord lawfully made under this title . . i is entitled, without the authority of the copyright owner, to sell or otherwise dispose of the possession of that copy or phonorecord.").

152. See, e.g., Leegin Creative Leather Prods., Inc. v. PSKS, Inc., 551 U.S. 877 (2007) (abandoning per se rule in resale price maintenance cases); Weyerhaeuser Co. v. RossSimmons Hardwood Lumber Co., 549 U.S. 312 (2007) (adopting narrow tests for liability for predatory bidding cases); Verizon Commc'ns Inc. v. Trinko, LLP, 540 U.S. 398 (2004) (adopting a narrow view of duties to deal under the antitrust laws).

153. Penn Cent. Transp. Co. v. New York City, 438 U.S. 104 (1978).

154. Intel Corp. v. Hamidi, 71 P.3d 296 (Cal. 2003). 
original license. These multiple transactions help wring the last unit of value out of the underlying asset. Accordingly, the state should not impose restrictions on this right of alienation unless these can be strictly justified to protect the interests of other individuals. Under this view, the owner of property is not under any duty to make an outright sale of a property. Instead, it is possible to lease it for a term of years, whereby the lessee gains exclusive rights to the premises for the duration of the lease. Alternatively, an owner can give a nonexclusive license to use some resources. In each case the owner will have to bear the costs of any restriction imposed, for he will not be able to charge the same price for a limited interest as for an expanded one and will incur the costs of monitoring licensee use to guard against violations. The restrictions in question therefore will typically be imposed only where some collateral gain justifies the cost in question. Therefore, except for a few (and controversial) efforts at monopolization, the normal rule is, and should be, one of freedom of contract. Unfortunately, modern patent law has developed two distinctive limitations on freedom of contract that require separate discussion: the removal of licensee estoppel and the first sale doctrine. In addition, the patent law has imposed restrictions on the right to alienate causes of action for patent infringement. I consider each of these areas in turn.

\section{Licensee estoppel}

One insistent question in patent law is whether the general doctrines of estoppel apply to patent licenses, just as they do with leases of real property. Just that approach was taken by the California Supreme Court in Adkins $v$. Lear, Inc. ${ }^{155}$ There, the court was confronted with a patent license that in so many terms estopped the licensee from challenging the validity of the patent: ${ }^{156}$

$[O]$ ne of the oldest doctrines in the field of patent law establishes that so long as a licensee is operating under a license agreement he is estopped to deny the validity of his licensor's patent in a suit for royalties under the agreement. The theory underlying this doctrine is that a licensee should not be permitted to enjoy the benefit afforded by the agreement while simultaneously urging that the patent which forms the basis of the agreement is void. ${ }^{157}$

In effect, the court respected the mutual dependence of the contractual conditions. In so doing, the California Supreme Court showed a real mastery of

155. 435 P.2d 321 (Cal. 1967), vacated, 395 U.S. 653 (1969).

156. Justice Mosk wrote for a unanimous court: "Under the doctrine of licensee estoppel, Lear would be prohibited from challenging the validity of Adkins' patent if the agreement had not been validly terminated. Where a license agreement specifies the conditions under which termination may occur, those conditions must be satisfied in order to effect a valid termination." Id. at 331 .

157. Id. at 325-26. 
basic patent law principles in dealing with various claim construction issues. But for our purposes the key proposition was that it treated the proper construction and enforcement of the license solely as a matter of state law. ${ }^{158}$ Accordingly, the court then applied the general rule to construe the agreement in light of the expressed intentions of the parties. Its careful examination of the agreement led it to conclude that the corporate licensee, Lear, could not lawfully terminate the agreement simply because some of Adkins's patent claims had been rejected. The case contained no discussion of any distinctive public policy issues raised by patents. The concordance between the general rules for licenses and those for patent licenses was complete.

When the case reached the Supreme Court, the entire mood of the discussion changed. Justice Harlan, writing for a unanimous Court, first noted that the California (state) law view on license estoppel followed earlier Supreme Court precedent on the subject. ${ }^{159}$ But the Court reexamined that prior doctrine in light of other decisions in intellectual property "emphasizing the strong federal policy favoring free competition in ideas which do not merit patent protection." 160 It then resolved the conflict between general contract principles and the patent law as follows:

Surely the equities of the licensor do not weigh very heavily when they are balanced against the important public interest in permitting full and free competition in the use of ideas which are in reality a part of the public domain. Licensees may often be the only individuals with enough economic incentive to challenge the patentability of an inventor's discovery. If they are muzzled, the public may continually be required to pay tribute to would-be monopolists without need or justification. We think it plain that the technical requirements of contract doctrine must give way before the demands of the public interest in the typical situation involving the negotiation of a license after a patent has issued. 161

In reaching its distinctive conclusion under the patent law, the Court did not find any functional justifications for the "technical requirements" of contract law. In so doing it missed the fundamental difficulty associated with the problem for both real and intellectual property. The hidden cost of the Court's rule relates to the willingness of individuals to license their property in the first place. That willingness will be reduced in all cases if the putative licensor knows that the licensee can take information acquired through the license arrangement and use it for a host of other purposes, including

158. The federal courts have exclusive jurisdiction over actions arising under patent laws, but where a plaintiff seeks to enforce a patent licensing agreement, the action "is not a suit under the patent laws of the United States, and cannot be maintained in a federal court as such." Id. at 325 (quoting Luckett v. Delpark, Inc., 270 U.S. 496, 502 (1926)).

159. Lear, Inc. v. Adkins, 395 U.S. 653, 656 (1969).

160. Id.

161. Id. at $670-71$. 
undermining the validity of the patent. The same issue appears to arise whether the decisive information is acquired by examining the recorded deeds in the chain of title for leased property or the various records involved in the creation of the license. The risk of the Lear rule is therefore that it induces patent holders to be choosier in the selection of their licensees, and to be charier in the sharing of information with the licensees whom they do choose, thereby rendering the licenses less valuable to both sides. This cost is borne in all cases, not just those in which there are successful claims of invalidity, some of which are likely to be erroneously decided. The upshot, therefore, is that the number of licenses, the kinds of licenses, and the licensee royalties will all change in response to the alteration of the legal rule. Indeed, any uncertainty about the validity of the agreement reduces the level of peaceful coexistence that the two sides can expect from the dealing. Finality matters as much with patents as with all other business arrangements.

The issue, then, is whether the distinctive feature of patent monopolies requires an alteration of the general rule of estoppel, to which the answer appears to be negative. The argument cannot be that the Supreme Court's rule has no advantages, for on the plus side it would lead to exposing more invalid patents. But how strong is that effect in light of the disruptions already mentioned to the voluntary licensing system? There are two answers. First, the standard patent is obtained only by a full and accurate description of its claims, and is always subject to nullification by any party who conducts a successful search of public materials for prior art that teaches the patented technology or shows that the patentee's initial disclosure was insufficient. There is no similar threat to the validity of the standard real estate leases. These third-party patent challenges, which have never been touched by the doctrine of estoppel, have often proved successful. Allowing the licensee to sue adds little by way of additional deterrence to filing defective patents. The shorter duration of the patent, relative to other kinds of lease arrangements, means that the dislocation is less pronounced in this area than for long-term real estate transactions.

Second, removing estoppel is not a targeted method for challenging patent abuses. To be sure, there may well be some case in which the patentee and the licensee have an interest in seeking to control and divide a market in ways that could run counter to the antitrust laws, which have little patience for horizontal divisions of markets and price fixing. There is, for example, in connection with the Hatch-Waxman Act, ${ }^{162}$ an extensive body of case law that addresses the question of whether a settlement between the incumbent patentee and the first

162. Drug Price Competition and Patent Term Restoration (Hatch-Waxman) Act of 1984, Pub. L. No. 98-417, 98 Stat. 1585 (codified as amended in scattered sections of 15, 21 , 35, and 42 U.S.C.). The Act established a fast-track method for approval of generic drugs, along with strategic protections for the brand-name manufacturers-an attempt to encourage entry but also respect existing patent rights. 
new entrant should be subject to liability under section 1 of the Sherman Act. ${ }^{163}$ Allowing these licensing agreements to be unenforceable could very well help prevent these collusive agreements. The problem is more complex than might appear because oftentimes these agreements arise out of settlements of infringement actions brought against the new entrant. Clearly the policies of the antitrust law may conflict with the desire to make bona fide settlements of disputes. And it could easily be that no such settlement should be enforceable unless there is some judicial oversight to deal with third-party interests. But no matter how this tension is resolved, the antitrust laws are a far better vehicle to deal with this question than the basic rules of licensee estoppel, which apply across the board whether or not there is any antitrust offense lurking in the background. Once again, covert tools are bad tools in dealing with these issues. The Supreme Court is right to allude to competition issues in Lear, but wrong to think that they are strong enough to countenance the wholesale destruction of the voluntary market when the antitrust law provides a more focused response.

The one silver lining in the Lear rule, as applied in the lower courts, was that it appeared that the licensee had to throw off the license in order to maintain the challenge to the underlying patent. At that point, the licensee ran the serious risk of being found guilty of willful infringement, and thus subject to heavy financial risks. Nor could the licensee continue to receive any of the collateral benefits supplied under that license agreement. The question that arises, therefore, is how far the appeal to public policy goes in upsetting the standard principles of contract. Just this question has been ducked for the time being in MedImmune, Inc. v. Genentech, Inc. ${ }^{164}$ The major unresolved issue is

163. Sherman Act, 15 U.S.C. $\S 1$ (2006). Two particular infringement settlement agreements, which were both condemned as anticompetitive, involved patented brand-name firms paying monthly or quarterly fees to the generic manufacturer to stay off the market during litigation and not to waive its statutory 180-day period of exclusivity. See In re Cardizem CD Antitrust Litig., 105 F. Supp. 2d 682 (E.D. Mich. 2000) (finding payments to the generic manufacturer to be naked market allocation that was per se illegal under section one of the Sherman Act), aff'd, 332 F.3d 896 (6th Cir. 2003); In re Abbott Labs., No. C3945, 2000 FTC LEXIS 65, at *14 (May 22, 2000) (alleging that the "purpose and effect" of the payment was to prevent entry). There has been rich scholarly debate on the social desirability of allowing, prohibiting, or restricting such agreements. See, e.g., Daniel A. Crane, Ease Over Accuracy in Assessing Patent Settlements, 88 MinN. L. REv. 698 (2004); Daniel A. Crane, Exit Payments in Settlement of Patent Infringement Lawsuits: Antitrust Rules and Economic Implications, 54 FLA. L. REV. 747 (2002); Herbert Hovenkamp, Mark Janis \& Mark A. Lemley, Anticompetitive Settlement of Intellectual Property Disputes, 87 MINN. L. REV. 1719 (2003).

164. 549 U.S. 118 (2007). This decision went off on various procedural questions about declaratory judgments. The Federal Circuit had previously held that so long as the licensee was in good standing under the terms of the patent, the licensee could not maintain a declaratory action, thereby ruling out all efforts to attack the validity of a patent under which payments were raised. See MedImmune, Inc. v. Genentech, Inc., 427 F.3d 958, 962-63 (Fed. Cir. 2005). The liberalized Supreme Court declaratory judgment rules open up this possibility. 
whether a licensee is entitled to continue to take advantage of the full benefits received under the license agreement so long as he keeps royalty payments current, while at the same time challenging the validity of the patent. If so, the resulting risks to licensing are exponentially larger than under Lear.

Indeed, it is an open question whether any two parties could ever settle a patent dispute with a license agreement that the licensee could not seek thereafter to upset by another round of litigation. The protection of competition is only one goal of the general patent law-and one often achieved by a legal system that encourages innovation so as to create competitive patented technologies. A second major goal of any legal system is to secure the stability of expectations such that people can plan today the distribution of rights that they wish to enjoy tomorrow. It seems very clear that the disregard of standard contractual protections carries with it social as well as private losses.

\section{First sale}

The alienability of intellectual property licenses has also been attacked under the first sale doctrine, both in copyright and patent law. Thus copyright law contains the explicit statutory "first sale" doctrine set out earlier. The analogous doctrine of patent law is developed judicially under the rubric of patent exhaustion, ${ }^{165}$ even though the first sale label used in copyrights seems more accurate. ${ }^{166}$ However styled, both areas are amenable to the same analysis. In principle the proper approach to all these consensual restraints on alienation is to allow them unless it can be shown that the prohibition against resale is intended to bolster the monopoly position of a firm with market power-the standard antitrust concern. ${ }^{167}$ This simple application of the existing principle is but one more effort to integrate intellectual property with other areas of law, so that there is no need to face the overlap between rival systems of law. As Scott Kieff and Troy Paredes have noted, straightforward application of existing legal frameworks, or a "basics approach," avoids the risk of "one-off doctrines" where intellectual property law intersects with other

165. See Quanta Computer, Inc. v. LG Elecs., Inc., 128 S. Ct. 2109 (2008) (adopting the "exhaustion" doctrine to bar patentee suit against the subsequent lawful purchaser of the patented item).

166. See Judge Giles S. Rich, Luncheon Address at the Sixth Annual Conference on International Intellectual Property Law \& Policy at Fordham University School of Law (Apr. 16, 1998), in F. SCOTT KIEFF ET AL., PRINCIPLES OF PATENT LAW 1144 (4th ed. 2008).

167. For one illustration of the restraints on alienation in the context of the Sherman Act, see United States v. United Shoe Mach. Corp., 110 F. Supp. 295 (D. Mass. 1953), aff'd per curiam, 347 U.S. 521 (1954). I cannot discuss these issues here, except to mention that in most cases the restraints on alienation do little to advance the monopoly position of the dominant firm. For my views, see RichaRd A. EPSTEIN, ANTITRUST CONSENT DECREES IN THEORY AND PRACTICE: WHY LESS IS MORE 40-53 (2007). 
areas of law, including antitrust. ${ }^{168}$

As noted earlier, the first sale doctrine in copyright law eliminates the ability of the copyright holder to restrict the otherwise unhindered first acquirer of a copyrighted article to transfer the copyrighted article to a third person. ${ }^{169}$ In these cases, the transfer of a single copyrighted article does not in and of itself appear to raise any particular antitrust concerns. The hallmark for antitrust in cases of single firms is the existence of some degree of market power, which is always lacking when any individual copyrighted work has to compete in a broad marketplace teeming with substitute works. In this context, it is far from evident that the basic copyright law should include a first sale doctrine that undermines freedom of contract by invalidating consensual restrictions of any further sale or disposition. These restrictions on contractual freedom can never be justified by the question-begging assertion that they are inconsistent with the "inherent" nature of chattels or copyrighted works. The same language has often been used, with equally little content, to justify knocking out various consensual restrictions on the alienation of real property on the equally uninformative ground that these restraints are "repugnant" to the underlying interest. $^{170}$ Finding a systematic negative externality generated by these restrictions is needed for justifying their imposition. Since patents and copyrights don't pollute, it is far more difficult to find these in the world of intellectual property than in ordinary physical space.

The weakness of the current legal position is made evident by the strong contrast it articulates between sales (or outright transfers) and licenses of particular works, whereby the transferor holds some retained interest in the underlying property. Here, the underlying property is the article of commerce, not the copyright. In its standard formulation, the first "sale" doctrine does not apply to limited licenses, even though it applies to sales and any other outright transfer of a copyrighted work that the original copyright holder makes to an initial recipient. That is the force of the words "otherwise dispose" in the statutory provision. ${ }^{171}$

The relevant issues came into sharp relief in a recent decision involving promotional CDs: UMG Recordings, Inc. v. Augusto. ${ }^{172}$ In that case, UMG had issued a series of promotional (stripped down) CDs free of charge to insiders in the Hollywood scene in order to promote the full CD before selling it to the general public. All promotional CDs were labeled (so as to give notice to third

168. Kieff \& Paredes, supra note 8, at 179.

169. See Quality King Distribs., Inc. v. L'anza Research Int'l, Inc., 523 U.S. 135, 152 (1998) (placing the copyrighted item in the stream of commerce means the copyright holder "has exhausted his exclusive statutory right to control its distribution").

170. See, e.g., CAL. CIV. CODE $\S 711$ (West 2009) ("Conditions restraining alienation, when repugnant to the interest created, are void.").

171. 17 U.S.C. $\$ 109$ (a) (2006).

172. 558 F. Sipp. 2d 1055 (C.D. Cal. 2008). 
parties) with the following legend:

This $C D$ is the property of the record company and is licensed to the intended recipient for perscnal use only. Acceptance of this $C D$ shall constitute an agreement to comply with the terms of the license. Resale or transfer of possession is not allowed and may be punishable under federal and state laws. ${ }^{173}$

With obvious knowledge of the restrictions, the defendant sold them to third persons on eBay. The plaintiff then sued on the terms of the license to block the sales. The defendant prevailed in this case on the strength of the first sale doctrine. The logic of the decision, and its errors in principle, require some discussion. The initial point is that current law permits these restrictions under licenses but not for sales, so that someone has to decide what kind of transaction was at stake. Since matters of public policy were invoked to invalidate the restrictions on subsequent alienation, any characterization of the transaction that the transferor makes is not decisive. The question then is how licenses should be functionally distinguished from sales. Two tests present themselves: The first is whether the licensor retained any interest in the CD, so as to be able to call for its return. That return was not required. The second question is whether the transferee bears any risk of loss in the transaction that reflects the ownership claims of the transferor. Again, the answer is in the negative. It follows therefore that the transaction is an outright gift (since free of charge) and not a license. The transaction is therefore caught by the first sale rule. Notice is immaterial and the request for an injunction fails.

It is therefore hard to quarrel with the result in Augusto under hornbook law. But recall the overarching inquiry is whether the statutory result is sound as a matter of first principle. And here the clear result should come out the other way. The initial point to note is that the only situation in which the restraint on alienation makes sense is if the transferor is seeking to obtain some monopoly profit, which seems hardly likely from the mass distribution of copies of the promotional CD. But even if we treat market power as irrelevant, Augusto is not a case where the original owner is seeking to gain revenues on both sales, or even on the second sale alone. Recall that the initial transaction was a gift, so that the copyright holder exacted no price at all. Rather, the object of the original transaction was to allow influential opinion leaders to hear the record in order to promote its sale more widely, which works to the benefit of both the copyright holders and potential purchasers of the $C D$. This transaction seems, therefore, to be largely immune to criticism on efficiency grounds.

The consequences of the erroneous decision are not benign. Augusto makes future promotional efforts more difficult. One possibility is that the copyright holder will require the insiders to pay for the $C D$ in order to recoup something from the anticipated future sale-a bad way to promote music. A second

173. Id. at 1058 . 
strategy is to require that the $\mathrm{CD}$ be returned on payment of a penalty, so as to make good the license characteristic. But those requirements are otiose, because the licensor has no need for the return of a promotional $C D$, nor the desire to endure the fuss and bother of collecting money for its no return. What is really desired in all these cases is feedback information about the performance, which could lead to its improvement, much as circulating drafts of an article allows an author to make revisions before final publication. So writing the provisions in the agreement is likely to lead to a policy of systematic non-enforcement so that the de facto gift characterization takes hold. And for what purpose?

The Copyright Act rules on first sale make no sense. Rather, the right way to look at first sale for copyrights is through the eyes of the uniform body of law on servitudes. The modern reform of servitudes in the Restatement calls (rightly) for the unification of the rules on easements and restrictive covenants, ${ }^{174}$ which thus returns the modern law to the Roman position. ${ }^{175}$ It also refuses to use any argument based on the inherent nature of these interests to limit their alienability, but candidly addresses the relevant policy issues by dealing with such matters as racially restrictive covenants and covenants in aid of monopolization. Its unified approach thus makes it wholly irrelevant whether the promotional CD transaction is characterized as a lease or a sale. All that matters are the principled grounds, if any, for the particular restraint on alienation. It is ironic that the people who freely champion the economic rationalization of intellectual property-Mark Lemley argued the case for Augusto -end up relying on solely formal grounds to defend the separate treatment of real and intellectual property.

The analogous doctrine to first sale in copyright is the principle of patent exhaustion. In its traditional form, the doctrine holds that the power of the patent is exhausted after its initial unrestricted sale, so that all future takers of the patented article take free and clear of any patent restriction. ${ }^{176}$ This rule tracks the rationale for the first sale doctrine in copyright. Make sure that the holder of the patent is entitled to exact only one fee for the sale of each object.

Once again, however, the rationale seems flawed, at least if the buyer of the original article is on notice of the restrictions that were contained in the original sale transactions, many of which may have been suggested by a buyer anxious to secure a lower price. The knowledge that some second payment will be required under the patent statutes will result in a reduction in price that the

174. Restatement (ThiRd) of Prop.: Servitudes $§ 1.1(2)$ (2000). For an account of the law offered by its chief draftsman, see Susan F. French, Highlights of the New Restatement (Third) of Property: Servitudes, 35 REAL PROP. PROB. \& TR. J. 225 (2000).

175. See, e.g., G. INST. 2.14, 2.31 (W.M. Gordon \& O.F. Robinson trans.).

176. See, e.g., Bloomer v. McQuewan, 55 U.S. (14 How.) 539, 549 (1852) (holding that actions against the assignee of a patented article go outside the "limits of the monopoly"). 
original purchaser will pay to the patentee. Indeed, if the fee for the second transaction is uncertain, all parties could lose from the arrangement. Accordingly, in most situations if the patentee wants to collect the maximum revenue for the sale or license of a patented item, he will do well to exact a single charge in the first instance in order to remove that residual uncertainty, thereby increasing overall revenues.

What then should be made of those cases in which the patentee, despite this consideration, still wishes to impose this restriction on sale? The exaction of monopoly profit does not seem the likely answer in these cases, given the logic stated above. Hence it becomes important to ask if there is any efficiency gain in question. That issue is often hard to determine, but it is instructive to note that many of the cases involving the patent exhaustion doctrine involve potential tie-ins that also raise antitrust concerns. For example, in Morton Salt Co. v. G.S. Suppiger Co., ${ }^{177}$ the Supreme Court held unenforceable a patent over a machine for depositing salt tablets because it was a tied-sale that required the buyer to purchase Morton's unpatented salt tablets. In this particular instance, the correct question to ask is whether the tie-in arrangement should be regarded as an effort to extend or lever a monopoly position into a second area by virtue of the tie.

Under the antitrust law of that period, such a tie-in was treated as a per se violation of the antitrust law so long as the defendant firm possessed the requisite degree of market power. ${ }^{178}$ More concretely, in the antitrust context, Justice Stone rejected the various efficiency explanations for the tie, including using the salt consumption as a way to monitor the intensity of use of the equipment so as to allow for price discrimination among buyers. That hostile attitude toward tie-ins has been moderated by the subsequent movement toward the rule-of-reason analysis in tie-in cases. ${ }^{179}$ Accordingly, the key point to note throughout is that the sensible approach to restraints on alienation in patents should rest on antitrust principles, and not on some special idea of patent misuse that extends more, or less, broadly than the general doctrine. On this point, some authority in the Federal Circuit treats the misuse doctrine under the patent law as somewhat broader than it is under the antitrust law. ${ }^{180}$ But the integration of antitrust and patent law should preclude this ad hoc response. ${ }^{181}$ In this instance, the categorical denunciation of tie-ins should, as has happened, fall by the wayside in both cases.

177. 314 U.S. 488 (1942).

178. Int'l Salt Co. v. United States, 332 U.S. 392 (1947).

179. See Jefferson Parish Hosp. Dist. No. 2 v. Hyde, 466 U.S. 2 (1984).

180. C.R. Bard, Inc. v. M3 Sys., Inc., 157 F.3d 1340, 1372 (Fed. Cir. 1998).

181. See Herbert Hovenkamp, The Antitrust EnTERPrise: Principle AND EXECUTION 273 (2005) (noting that "the Federal Circuit's position seems incredible to someone familiar with the expansive body of antitrust doctrine," given that " $\$ 2$ [of the Sherman Act] reaches every act that monopolizes or dangerously threatens to do so"). 
The 1952 Patent Act introduced provisions that limited the scope of the patent misuse doctrine, ${ }^{182}$ which moves strongly in the direction of integrating the two systems. Just recently, however, the Supreme Court took a (unanimous) step backwards in its decision in Quanta Computer, Inc. v. LG Electronics, Inc. ${ }^{183}$ which held that the exhaustion doctrine applied in this three-cornered situation. LG Electronics (LGE) had entered into an agreement (pursuant to the settlement of a patent dispute) that allowed Intel to obtain a limited license to LGE's patented technology at a price lower than that which it would have had to pay for an unlimited license. As part of that agreement, Intel agreed to give notice to all third-party purchasers of Intel's chips that they had to obtain a license from LGE in order to use the patented technology. Intel gave the required notice to Quanta, which in turn claimed that it took Intel's patented microchips free and clear of any obligation to LGE under the patent exhaustion doctrine.

One instructive issue in the case was whether the restraints in the LGE/Intel settlement could attract any attention under the antitrust law. That question was not explicitly addressed by Justice Thomas in his opinion, but it was addressed by the petitioner Quanta in its brief. There, Quanta took the position that the inability to show an antitrust violation did nothing to limit the scope of the exhaustion doctrine. ${ }^{184}$ Taking a leaf from Julie Cohen and Mark Lemley, Quanta argued that although any contract right to sell free and clear is subject to disclaimer, the same is not true with the patent exhaustion doctrine which "stems from inherent limits on the grant of the patent right," and not on the shared expectations of the parties to the transaction. ${ }^{185}$ Missing of course is any explanation as to why the contract principles should not override this "inherent" doctrine and allow the patent infringement suit to be brought against the subsequent taker.

To add to the confusion, Justice Thomas in Quanta noted that his opinion did not express any opinion on the validity of any breach-of-contract claim that LGE might have included in its suit against Quanta. ${ }^{186}$ Yet that suggestion opens only more uncertainty. It is highly unlikely that LGE had entered into any direct contract with Quanta, given that the sale was by a third party. So the remaining question is whether it could claim to be a third-party beneficiary of any contract between Intel and Quanta, assuming that the Intel-Quanta deal included such a provision. But that claim is surely weaker than the patent

182. Patent Act of 1952 , ch. $950, \S 1,66$ Stat. 792 (codified as amended in scattered sections of 35 U.S.C.). The relevant provision is 35 U.S.C. $\$ 271(d)(2000)$.

183. 128 S. Ct. 2109 (2008).

184. Brief for Petitioners at 30-33, Quanta Computer, Inc. v. LG Elecs., Inc., $128 \mathrm{~S}$. Ct. 2109 (2008) (No. 06-937).

185. Id. at 26 (quoting Julie E. Cohen \& Mark A. Lemley, Patent Scope and Innovation in the Software Industry, 89 CAL. L. REV. 1, 31-32 (2001)).

186. $128 \mathrm{~S}$. Ct. at 2122 n.7. 
claim. For one thing, the contract claim does not give rise to a federal cause of action, and for another, it is subject to any standard defenses that could be raised in ordinary contract actions.

More to the point, if any such contract were valid, why not allow the agreement between Intel and Quanta to waive the patent exhaustion rule for sensible business reasons? In Quanta, for example, it makes perfectly good business sense that settlements between the parties not increase or decrease rights against third persons. Indeed, in this context, there is a simple explanation for the notice provision that does not depend on any sophisticated account of price discrimination. The notice function allowed for the integration of various LCE licenses. More concretely, it seems as though some parties who acquired chips from Intel had already obtained a blanket license from LCE for its embedded technology. ${ }^{187}$ That notice provision assured these parties that they would not be required to pay a second time for a license that they had already acquired. That notice provision would also warn other parties that an additional payment was required. Prior to purchase, therefore, they could make inquiries to LCE for its license rate to make sure that they were satisfied with the total license fee paid. The efficiency rationale of this two-part payment system seems too evident to question.

None of this business context was reflected in Justice Thomas's opinion in Quanta, which was a pure exercise in idle formalism. At no point does it indicate why contract principles should not control in light of the sensible restrictions of antitrust policy. Indeed the word "default" never appeared in his opinion (or for that matter in the Petitioner's Brief), even though many of the earlier cases that involved the patent exhaustion doctrine were rife with antitrust concerns.

By way of example, United States v. Univis Lens Co. ${ }^{188}$ discussed the patent exhaustion doctrine in connection with the government's claim for illegal resale price maintenance under the antitrust laws, which at that time was a per se offense, ${ }^{189}$ but is now governed by a rule of reason standard. ${ }^{190}$ It is

187. Robert W. Gomulkiewicz, The Federal Circuit's Licensing Law Jurisprudence: Its Nature and Influence, 84 WASH. L. REV. 199, 233 (2009) (noting that the exception in the Intel license "is good news for computer-system manufacturers who have a patent portfolio cross license with LG Electronics. These companies already paid for the patent rights. They do not want to pay again as part of the price of Intel's microprocessors. For those manufacturers who do not have such a license, however, Intel cannot serve as a "reseller" of LG Electronics' patent rights. These manufacturers must purchase their patent rights directly from the patentee, LG Electronics"). My thanks to Rochelle Dreyfus for pointing out this article, which fills a big hole in the business back story of the case.

188. 316 U.S. 241 (1942). Note that the result in Univis does not survive the addition of 35 U.S.C. $\S 271$ (d) (2006), sharply limiting the situations in which the patent abuse doctrine supplies an affirmative defense against actions for patent infringement or contributory infringement.

189. Dr. Miles Med. Co. v. John D. Park \& Sons Co., 220 U.S. 373 (1911). 
notable that the gist of Univis' case was whether the patent somehow immunized Univis from the application of the antitrust law, to which the answer should of course be no. At no point, however, did Justice Thomas's opinion in Quanta so much as address whether the patent exhaustion doctrine should be treated as a default rule of contract, subject to variation by contrary agreement except when it flouts the antitrust laws. Those points were explicitly raised, moreover, in the amicus curiae brief authored by Scott Kieff, Troy Paredes and Polk Wagner, ${ }^{191}$ which I happily signed.

The overall picture is not pretty. The restrictions on alienation have profound influence on the ability to commercialize products. Yet the willingness to impose these restraints rests not on careful analysis of these consequences, but instead on a set of arid technicalities of no particular value. The irony at this juncture is palpable. The attack on the classical liberal conception of property rests on the notion that it suffers from excessive formality, which drives today's strict rules on exhaustion and first sale. Everyone concedes that the creation of intellectual property has at its root explicit utilitarian justifications.

Yet the concrete cases fail to link up to any body of law that seeks to respond to these issues. As Kieff and Paredes rightly point out, this willingness to go it alone does not necessarily result in either stronger or weaker intellectual property protection. ${ }^{192}$ The government should have prevailed in Univis, for example, if resale price maintenance was a per se offense under the antitrust law, but otherwise should be forced to build up its case under the rule of reason. It would be odd to allow the patent law to go its separate way now that the antitrust law has concluded that mere possession of a patent does not create any conclusive presumption of market power. ${ }^{193}$ Yet the Court in Quanta did not show the slightest awareness that its dubious use of the patent exhaustion doctrine went a long way to reinstitute the discredited per se rule against tie-ins of International Salt. ${ }^{194}$ When combined with the eBay, Inc. $v$. MercExchange, L.L.C. ${ }^{195}$ decision on injunctive relief, these decisions on first sale and patent exhaustion show unmistakably that the rights of exclusion and disposition are under sustained attack in the world of intellectual property. Never have the classical liberal rules on those topics looked so good. The only systematic deviation in patents and copyrights from the rules governing land and chattels concerns the issue of duration.

190. Leegin Creative Leather Prods., Inc. v. PSKS, Inc., 551 U.S. 877, 882 (2007).

191. Brief of Various Law Professors as Amici Curiae Supporting Respondent at 6, Quanta, 128 S. Ct. 2109 (No. 06-937) (citing case law treating the exhaustion rule as a default provision); $i d$. at 9 (raising the antitrust concern).

192. Id. at 14.

193. See Ill. Tool Works, Inc. v. Indep. Ink, Inc., 547 U.S. 28, 31 (2006).

194. 332 U.S. 392 (1947).

195. 547 U.S. $388(2006)$. 


\section{Rights of action}

Another variation on the basic problem of alienation is directed not to the sale of the patent or copyright, but to the alienation of a right of action against any infringer. These cases raise additional complications that are not present in the sale or license area of intellectual property. As before, the initial premise remains: the division of the property interest does not impose any additional obligations on strangers. Their obligation is still limited to forbear from use, which they can satisfy whether the patent or copyright resides in one party or is divided among a thousand. Indeed, in these situations, divided interests could improve the position of the infringer given that the holders of the individual pieces usually do not have large enough stakes to maintain any action. Knowing this in advance, the interest holders can designate one of their number as the lead plaintiff in any future lawsuit in order to consolidate those claims, which leaves the position of the outsider relatively unchanged.

Yet here we run into two related questions. The first is whether the right of action may be separated from the ownership of the underlying patent. The second is whether the right of action against infringers can be divided among various persons. On these key matters the patent law again contains puzzling doctrines that purport to flow from the inherent nature of the patent grant, but which once again are in tension with the basic rules on alienation outlined above.

Once again the analogy to other forms of property is instructive. Judges have long been worried about the alienation of claims against specific persons, whether it be for the collection of a debt or the enforcement of a contract, including of course various kinds of licensing agreements. In these circumstances, the assignment or fractionalization of interests could increase the burden on the obligor, which is what happens, for example, with the assignment of part of a debt. ${ }^{196}$ One application of this principle asks whether individuals to various sale and licensing agreements are entitled to assign the right to sue for breach of obligation while retaining all other interests. This question commonly arises in connection with the alienation of tort claims, where the contingent fee should be understood as a partial alienation of claim to the lawyer who takes over its prosecution. ${ }^{197}$ But in principle there should be no opposition to selling the entire tort claim to third persons, either before or

196. Consider the protection provided for the obligor in RESTATEMENT (SECOND) OF CONTRACTS $\S 326(2)$ (1981) ("[N]o legal proceeding can be maintained by the assignor or assignee against the obligor over his objection, unless all the persons entitled to the promised performance are joined in the proceeding ....").

197. On the relationship, see generally James D. Dana, Jr. \& Kathryn E. Spier, Expertise and Contingent Fees: The Role of Asymmetric Information in Attorney Compensation, 9 J.L. ECON. \& ORG. 349 (1993). 
after it matures. ${ }^{198}$ (Selling it to the potential defendant in a tort action is just a variation on the old theme of assumption of risk.)

Nonetheless there is resistance to this contractual approach in patent law. One instructive decision is Crown Die \& Tool Co. v. Nye Tool \& Machine Works, ${ }^{199}$ which found it incompatible with patent law to allow the patent holder to sever the right to sue an infringer from the other rights in the bundle. "[T]he plaintiff in an action [for infringement] must be the person or persons in whom the legal title to the patent resided at the time of the infringement." 200 The question here is why. To be sure, the patentee will usually be the party who will want to retain the right to sue, since he is the party that loses from any act of infringement. But suppose, as in Crown Die, the explicit agreement states that the assignor shall receive for valuable consideration the right to sue a given defendant for its infringement. The Supreme Court, through Justice Taft, nonetheless invalidated the assignment on the ground that the right to exclude (which was created by the patent statutes) could not be separated from the related common law rights to "make, use, and vend" the objects in question. ${ }^{201}$ But even if we assume that the usual patent rights are an amalgam of common law and statutory elements, why does the assignment offend? The only functional explanation that is offered is one that looks to the increased burdens on third parties, which arise when

the right to make, use and vend, but gives to many different individuals the right to sue certain named infringers, respectively, and that with the sole motive of harassing them such as is avowed in the recitals of the instrument before us. If held legal, it would give the patentee an opportunity without expense to himself to stir up litigation by third persons that is certainly contrary to the purpose and spirit of the statutory provisions for the assigning of patents. ${ }^{202}$

That result would be correct if multiple parties received the right to sue the same defendant for multiple breaches, but in this case the assignment from the original holder of the patent only allowed one party to maintain all claims under this patent against this defendant, effectively negating the risk of duplicative litigation. The reason for the assignment seems to be that the assignee of the individual claim was a cheaper enforcer of the patent right in question, so that the entire assignment should be welcomed on the ground that it reduces the likelihood of infringement in the first place. No one has a constitutional right to be immune from valid suit because the wrong party holds the claim. We allow generally for class actions to amalgamate small claims that

198. Marc J. Shukaitis, A Market in Personal Injury Tort Claims, 16 J. LEGAL STUd. 329 (1987).

199. 261 U.S. 24 (1923).

200. Id. at 40 .

201. Id. at 39 .

202. Id. 
would otherwise not be brought, and we allow people to sell liquidated claims against third persons. Accordingly, there seems no reason why that same rule should not apply to unliquidated claims so long as the assignee of the entire claim is bound by the same constraints, and subject to the same defenses, as the original holder.

Despite its uneasy origins the rule in Crown Die has been applied to other cases which raise similar concerns. One standard question in this area is whether the holder of a nonexclusive license is entitled to maintain a suit for patent infringement. Here the parallel question for real property is whether the nonexclusive licensee of real estate is entitled to sue for nuisance, to which the general answer is no. ${ }^{203}$ The explanation is that multiple suits fragment the basic claim and thus impose additional burdens on the outsider, at a time when the action by either the landowner or occupier is sufficient to deal with the issue at hand. A similar rule could easily apply to intellectual property. So long as the patent holder maintains the right for suit, there is no need to sort out the relative claims of individual licensees to sue. That position is generally adopted, but not always for the right reason. Thus in Mars, Inc. v. Coin Acceptors, Inc., the court held that a wholly owned subsidiary corporation lacked constitutional standing to sue for its losses on a nonexclusive license from its parent. ${ }^{204}$ It could no longer, however, recover a higher measure of lost profits given that it had made a nonexclusive license to its wholly owned subsidiary. ${ }^{205}$

Mars thus turned on the proposition that "[o]nly a patent owner or an exclusive licensee can have constitutional standing to bring an infringement suit; a non-exclusive licensee does not." 206 The issue here bears an eerie similarity to the view that somehow the nonexclusive licensor cannot pursue injunctive relief under $e B a y{ }^{207}$ But why the result? As a constitutional matter, surely there seems to be some injury in fact to the licensee. That would surely be the case if the right of suit were expressly assigned. Why not allow that action when it is to the advantage of both the parent and subsidiary, parties that did not divide their claims to benefit a third party? It is therefore best to put the constitutional question to one side, and instead look to how the issue should be approached as a matter of general theory. In these cases, the nuisance argument works well so long as the patent holder could obtain the full damages for the loss, just as if the license had never been issued. The suit by a single party would simplify matters by preventing multiple suits by each nonexclusive licensee. That result makes good sense; for if the nonexclusive licensee could

203. See, e.g., Malone v. Laskey, [1907] 2 K.B. 141, 153-54.

204. 527 F.3d 1359, 1367-72 (Fed. Cir. 2008).

205. Id. at $1365-67$.

206. Id. at 1367.

207. See discussion supra pp. 493-494. 
not complain if the patentee issued more licensees, then, as a first approximation, it could not complain if the patentee allowed certain claims to slide by.

But the next step in the argument is what should happen if the patentee purports to vest its right of suit in one or all of its nonexclusive licensees. Here the only legitimate concern is the duplication of claims, which is avoided when the nonexclusive licensee becomes the sole representative, endowed with all the rights of the patentee. As with Crown Die, ${ }^{208}$ no infringer should be able to complain when the task of patent enforcement is placed in private hands, so long as only one party is entitled to press all claims arising from the patent against the infringer. In this case the situation is even more dramatic because the only interested parties were the parent and the subsidiary so that any allocation of right between them is at most a bookkeeping convenience, not a transfer of any economic interest.

At this point, the central proposition kicks in: the rights of a patentee should be neither diluted nor enhanced by issuing a nonexclusive license to its wholly-owned subsidiary. If the patent had been retained by the parent in full, it could have had the higher amount of reasonable royalties or lost profits. The transfer of its interest to a wholly-owned subsidiary-or indeed to any licensee-should not result in the windfall to a stranger to the agreement, which is what this decision creates in the infringer. A simple procedure that joins all potential claimants in one proceeding should be sufficient to avoid the risk of duplicative or inconsistent claims. The rule that nonexclusive licensees cannot sue is a good default approximation, but it should be one that the parties to the licensee agreement can override so long as the ultimate assignment of the cause of action does not lead to duplicative or inconsistent claims.

\section{Takings Questions}

The third area in which to explore the integration of real and intellectual property deals with the law of takings, and in particular the role of the critical Penn Central ${ }^{209}$ decision. In the real property cases, the Supreme Court has drawn (but not well defended) the strong line between the physical takinginvolving the occupation of private property by the state-and the "mere" regulation of that property - just limiting its use and disposition.

That distinction, however, makes no sense to a traditional private lawyer who thinks that all incidents of ownership are of equal dignity, so that all servitudes are properly treated as property interests. If a neighbor cannot impose a limitation on use or development by an owner without paying for it, neither can the government. Yet ironically, the difference between easements

209. 438 U.S. 104 (1978), discussed supra in text accompanying notes 65-71. 
(which are treated as possessory takings subject to a per se rule) ${ }^{210}$ and restrictive covenants (which are subject to the balancing tests of Penn Central) goes against the unification of these two areas that is the centerpiece of the recent Restatement on Servitudes. ${ }^{211}$ Under that unified theory, the only difference between the public and the private parties is that the state can force the owner to surrender that servitude which the ordinary individual must purchase in a voluntary transaction. Stated in its simplest form, the function of the Takings Clause ${ }^{212}$ is to allow the government to overcome the holdout problem in assembling property for public use; it is not to allow the state to acquire property for free. On this view, the right approach to takings always starts with the proposition that the government has to pay for what it has taken, no matter how much it has left behind. At this point the only tricky questions are those of valuation, whereby it can be asked whether the taking of one portion of the land increases or diminishes the value of the portion that the original owner has retained.

Unfortunately, the incoherence introduced by the law of regulatory takings has scarred intellectual property law. The first line of argument is that no per se rule can apply to takings of intellectual property because these interests, by definition, cannot be reduced to possession. But that position misses the obvious analogical extension. Within the current legal framework, any action that allows the government to use, or to authorize private persons to use, someone else's patent or copyright should be subject, right now, to the per se takings rules. ${ }^{213}$ To be sure, this opens up the government to serious valuation issues, but these are not any more complicated than the issues that arise in the condemnation of such complex issues as utility easements and power lines in both rural and urban settings. And in most cases, there is no reason to take the patent in the first place, as the voluntary licensing market works well, and there are no nuisance-like externalities that might justify limiting a patent use. Speaking generally, the dynamism of intellectual property markets tends to shorten the period of any economic monopoly by allowing the entry of new products into the market on ever shorter cycles, which is indeed the case. ${ }^{214}$

I believe that the full takings apparatus should apply to intellectual property as it does to physical property. But even if that position is not adopted, it seems clear that the current Penn Central rules should be limited to cases in

210. See Nollan v. Cal. Coastal Comm'n, 483 U.S. 825 (1987).

211. Restatement (Third) OF Prop.: Servitudes § 1.1(2) (2000).

212. U.S. CONST. amend. V.

213. For a development of this theme, see Richard A. Epstein, The Constitutional Protection of Trade Secrets Under the Takings Clause, 71 U. CHI. L. REv. 57 (2004).

214. Thirty-three years passed before a new entrant challenged the Edison phonograph. Only three years passed before the first competitor entered the new compact disc market in the 1980s. Rajshree Agarwal \& Michael Gort, First-Mover Advantage and the Speed of Competitive Entry, 1887-1986, 44 J.L. \& ECON. 161, 161 (2001). 
which the government restricts the use of the patent or copyright, at least where there is no concern with cartelization or monopolization. It has no application in cases where the government uses the patent itself or authorizes its use by other private individuals. The use of a patent is, in a word, no different from the use of land.

The permissive attitude of the Penn Central case, when coupled with the skeptical attitude toward intellectual property in general, can lead to destructive political dynamics in cases of simple expropriation. Recently, I wrote two lengthy letters ${ }^{215}$ to Senators Patrick Leahy and Arlen Specter, then Chairman and Ranking Member, respectively, of the Senate Committee on the Judiciary, on behalf of DataTreasury Inc. ${ }^{216}$ in opposition to Section 14 of the nowdefunct Patent Reform Act of $2007^{217}$ and its successor, the Patent Reform Act of $2008^{218}$ (which should remain defunct for many different reasons).

The key text reads as follows:

Section 287(d)(1) With respect to the use by a financial institution of a check collection system that constitutes an infringement under subsection (a) or (b) of section 271, the provisions of sections $281,283,284$, and 285 shall not apply against the financial institution with respect to such a check collection system. 219

A bit of explanation is necessary to clarify the underlying issues. The only patents to which this section could have applied were DataTreasury's U.S. Patent No. 5,910,988 (filed Aug. 27, 1997) ("the '988 patent") and U.S. Patent No. 6,032,137 (filed May 19, 1998) ("the '137 patent"), which discuss the creation of a system that utilizes machinery to electronically capture "paper transactions from documents and receipts" as electronic images. Put more commonly, the patents cover the technology that is used for the remote imaging of check and credit receipts. Multiple judicial challenges to the two patents proved fruitless, ${ }^{20}$ and the legislation in question was not drafted to contest the validity of the patents, which was why it covered any case of "infringement." It was also introduced to make sure that remedies for damages, injunctions, and legal fees could not be recovered for any such infringement.

The 2008 version of the bill went one step better, for it created an

215. Letter from author to Senator Patrick Leahy, Chairman, Senate Comm. on the Judiciary, and Senator Arlen Specter, Ranking Minority Member, Senate Comm. on the Judiciary (Oct. 29, 2008) (on file with author); Letter from author to Senator Patrick Leahy, Chairman, Senate Comm. on the Judiciary, and Senator Arlen Specter, Ranking Minority Member, Senate Comm. on the Judiciary (Apr. 2, 2008) (on file with author).

216. DataTreasury, Inc., http://www.datatreasury.com (last visited Aug. 29, 2009).

217. Patent Reform Act, S. 1145, 110th Cong. $\$ 14$ (2007).

218. Patent Reform Act, S. 3600, 110 th Cong. $\$ 13$ (2008).

219. Id.

220. DataTreasury Corp. v. Ingenico S.A., No. 5:02CV95, No. 5:02CV124, No. 5:03CV39, 2005 U.S. Dist. LEXIS 15782 (E.D. Tex. Feb. 28, 2005) (deciding three cases). 
exception to this rule of non-enforcement on behalf of financial institutions, which could sue if anyone violated one of their patents to a check collection system. ${ }^{221}$ And for good measure, it added a further provision, which prevented the application of this last exception for any company that transferred its patents to a financial institution in order to escape the basic statutory prohibition. ${ }^{222}$

There is no need to dwell on the ad hoc favoritism embodied in these provisions. But what is critical is that the entire scheme rests on the assumption that financial institutions can use the patented technology free of any and all legal restraints. Even under the restricted rules of the current legal framework, the only way to avoid the per se takings rule is to make the unsound argument that per se rules are impossible for intangible assets.

That proposition is, however, far from clear even under the current law. Nonetheless, Walter Dellinger and Christopher Schroeder, Professors at Duke University School of Law, wrote to Senators Patrick Leahy and Arlen Specter on behalf of their unnamed clients on O'Melveny \& Myers firm stationery ${ }^{223}$ an elaborate defense of Section 14 of the Patent Reform Act of 2007. I shall comment here only on their effort to justify this wholesale excision of patent protection on the strength of Penn Central.

The gist of their argument (which was wrong on the facts) relied on the claim that the patent in question only referenced documents, without explicitly referring to checks. Accordingly, under the "investment backed expectations" test of Penn Central, the patentee could be stripped of this particular right because it had no specific intention to apply its patent to this set of end uses. 224

221. Patent Reform Act of 2008, S. 3600, 110 th Cong. $\S 13(\mathrm{a})$, which reads:

This subsection shall not limit or affect the enforcement rights of the original owner of a patent where such original owner-

(A) is directly engaged in the commercial manufacture and distribution of machinery or the commercial development of software; and

(B) has operated as a subsidiary of a bank holding company, as such term is defined under section 2(a) of the Bank Holding Company Act of 1956 (12 U.S.C. 1841(a)), prior to July 19, 2007.

222. "A party shall not manipulate its activities, or conspire with others to manipulate its activities, for purposes of establishing compliance with the requirements of this subsection, including, without limitation, by granting or conveying any rights in the patent, enforcement of the patent, or the result of any such enforcement." Id. $\S 13(\mathrm{~d})(4)$.

223. Letter from Walter Dellinger, Professor, Duke Univ. Sch. of Law, and Christopher Schroeder, Professor, Duke Univ. Sch. of Law, to Senator Patrick Leahy, Chairman, Senate Comm. on the Judiciary, and Senator Arlen Specter, Ranking Minority Member, Senate Comm. on the Judiciary (Mar. 6, 2008) (on file with author) [hereinafter Dellinger \& Schroeder Letter].

224. Among the claims made were: "a method for central management, storage and verification of remotely captured paper transactions from documents and receipts" (Claim 26 of the '988 patent); "a method for central management, storage and verification of remotely captured paper transactions from checks" (Claim 26,'137 patent); "capturing an image . . . and extracting data therefrom" (Claim 46, '988 patent). Documents include checks as a 
It is important to quote the key paragraph in their argument:

The most basic reason for which we write is to rebut the initial suggestion that the Check 21 Amendment violates the Constitution. To allege a taking here is essentially to claim a constitutional right to whatever windfall profits may come a patent holder's way during the life of its patents, regardless of the public interest. If that were enough for a taking, it would confer on patents a status unknown to all other kinds of property, all of which are held subject to the possibility of reasonable regulation. After the Check 21 Amendment becomes law, affected patent holders will still have intact the ability to receive valuable and reasonable commercial gains from their patents, as evidenced by the fact that licenses have already been entered into with several companies. That is more than sufficient to satisfy their legitimate expectation. ${ }^{225}$

Their letter thus makes an ill-designed appeal to a set of integrated rules for all forms of property, after which it refers explicitly to the tripartite test in Penn Central. ${ }^{226}$ As might be expected, Dellinger and Schroeder do not write in a vacuum, for much of the critical writing on intellectual property has used just this framework to bolster its claims. Thus, Sara K. Stadler has recently written about the incentive-expectation circularity that exists in copyright law. ${ }^{227} \mathrm{Her}$ effort is to expose the confusion in the traditional economic arguments that copyrights are justified in order to promote the various arts. Her point is that if in a particular case the copyright holder has no expectation of a particular form of development, it cannot serve as an inducement for production, and thus is deserving of no protection at all.

That position has been elaborated in a recent article in the Harvard Law Review by Shyamkrishna Balganesh, ${ }^{228}$ who takes his cue from the foreseeability limitation on tort liability in negligence cases. The implicit, if much disputed, ${ }^{229}$ premise is that the tort law does not hold individuals

matter of ordinary usage, and checks were in any event explicitly covered.

225. Dellinger \& Schroeder Letter, supra note 223, at 2.

226. See id. at 3.

227. Sara K. Stadler, Incentive and Expectation in Copyright, 58 HASTINGS L.J. 433 (2007).

228. Shyamkrishna Balganesh, Foreseeability and Copyright Incentives, 122 HARV. L. REV. 1569 (2009).

229. Many cases prefer to use a directness test for the consequences of particular actions. See, e.g., In re Kinsman Transit Co., 338 F.2d 708 (2d Cir. 1964); Christianson v. Chi., St. P., M. \& O. Ry., 69 N.W. 640 (Minn. 1896); In re Polemis \& Furness, Withy \& Co., [1921] 3 K.B. 560. The leading authority the other way is still Overseas Tankship (U.K.) Ltd. v. Morts Dock \& Eng'g Co. (Wagon Mound I), [1961] A.C. 388 (P.C.) (appeal taken from Austl.). Academic response is divided. Compare Glanville Williams, The Risk Principle, 77 L. Q. R. 179 (1961) (looking to what risks the actor should have foreseen), with Heidi M. Hurd \& Michael S. Moore, Negligence in the Air, 3 THEORETICAL INQ. L. 333 (2002) (advancing that a harm-within-the-risk analysis is descriptively inaccurate and normatively undesirable). My sympathies are strongly with the directness principle, at least in stranger cases, which comports much better with a general system of strict liability that I have long supported. See Richard A. Epstein, A Theory of Strict Liability, 2 J. LEGAL STUD. 
responsible for unforeseeable consequences of their original negligence, because unavailable information does not allow parties to respond to incentives to avoid loss. By parallel reasoning, they do not respond to unforeseeable gains in the law of copyright in the creation of their writings and should not therefore receive protection for their "windfall" gains.

Beware! The use of the term "windfall" in property should immediately excite suspicion. Its literal definition is something that "falls" to a person by virtue of the "wind," like fruit from a wild tree. The point is that windfall gains are those that no individual did anything to either create or preserve. In these situations, it is exceedingly difficult to fix on any strong rule for one who owns the gains so generated. Nothing suggests that it is possible to incentivize individuals to engage in productive activities for these windfall profits. It is therefore no surprise that the decided cases often struggle over such questions as to whether the windfall belongs to the person who stumbles upon it, or to the person on whose property it was found, with inconclusive results. ${ }^{230}$

Alternatively, its broader definition refers to any unearned gain by some unexpected good fortune. In the usual case, those gains go to the owner of the property whose value has been increased, usually on the theory that the owner also takes the risk of unexpected losses attributable to acts of God, the inverse of the windfall gain. In any event, the whole point of using the term "windfall" to describe the accretion in value to a new technology is to make it appear as though it were wholly undeserved. But it hardly follows that the unanticipated gains fall into the public domain, when they could follow the usual rule and accrue to the owner. In any event, once the owner is aware of the prospect of copyright gains from future technologies that are as yet unknown, he will increase his efforts to produce those gains-which he will not do if the law assigns them to others. The ill-fated history of the Windfall Profits Tax on oil should be warning enough against the new use of the term. ${ }^{231}$

151 (1973).

230. Compare Bridges v. Hawkesworth, (1851) 21 L.J.Q.B. 75 (preferring the finder of money over the owner of the shop in which it was found), and Hannah v. Peel, [1945] K.B. 509 (preferring finder of brooch to owner of a house leased to military), with Elwes $v$. Brigg Gas Co., (1886) 33 Ch.D. 562 (preferring owner of land to finder of prehistoric boat embedded in the soil).

231. Crude Oil Windfall Profit Tax Act, Pub. L. No. 96-223, 94 Stat. 229 (1980) (repealed 1988). The Act was structured as a three-tiered excise tax that exempted some oil production in Alaska, prompting a constitutional challenge under the Uniformity Clause, Article I, Section 8, Clause 1 of the Constitution. See United States v. Ptasynski, 462 U.S. 74 (1983) (upholding the exemption since it was not "drawn on state political lines," and instead reflects "unique climatic and geographic conditions"). The Act was an attempt to capture and redistribute the increased revenues expected from the decontrol of crude oil prices. By the time it was repealed, the Act had led to an increase in dependence on foreign oil and was generating little to no revenue; it ultimately attained only twenty percent of its initial projections. See Salvatore lazzarl, Cong. Research Serv., The Crude Oil WindFall Profit TAX OF THE 1980s: IMPLiCations for CURRENT ENERGY POLICY, CRS 
Given its general appeal, however, it is no accident that the constitutional arguments of Dellinger and Schroeder track the same faulty language taken from the private law context. The first of these arguments has to do with the understanding of "reasonable expectations," which in many cases is open to the charge that the account of property rights is perfectly circular. ${ }^{232}$ It is yet another of the many false reasons to explain the supposed demise of the classical liberal system. The conceptual problem, we are told, is that reasonable expectations determine the appropriate legal rule, but at the same time we know that the expectations that people have are determined by the legal rules now in place. The expectations that determine the legal rules are thus determined by the legal rules that they are supposed to establish. Under that pinched view of the world, no person could have a reasonable expectation of privacy against private or government snooping because the legal rule could authorize the snooping and thus make it unreasonable to expect any other result. The cases on privacy in both the tort and criminal procedure contexts reject that interpretation. $^{233} \mathrm{~A}$ far better test is this: use the notion of reasonable expectation to identify that set of rules which optimizes the value of resources across individuals. ${ }^{234}$ Thus in connection with ordinary expectations of privacy, eavesdropping in restaurants is not allowed because it is "cheaper" for people not to lean over across tables than it is to have them situated far apart. Of course, persons can retreat to private rooms for sensitive discussions, but for general purposes, the value that all people have in maintaining their freedom of action and their security from intrusion is presumptively maximized by following this convention.

This approach removes the supposed circularity with respect to property rights. We know to a certainty that all individuals will claim the maximum rights which the law will give them. This claim of right is not vacuous given such restrictions as the central proposition that no person is entitled to copyright or patent a mere idea. The tradeoff is identical to that we observed

REP. No. RL33305, at 15 (2006).

232. See Stadler, supra note 227. For my critique of this notion in connection with takings of real property, see Richard A. Epstein, Lucas v. South Carolina Coastal Council: $A$ Tangled Web of Expectations, 45 STAN. L. REV. 1369 (1993).

233. See Katz v. United States, 389 U.S. 347, 353-59 (1967) (discussing reasonable expectations in the Fourth Amendment context); Roach v. Harper, 105 S.E.2d 564 (W. Va. 1958) (recognizing tort action for invasion of privacy by listening devices). For an explanation of how these rules are socially optimal, see Richard A. Epstein, Deconstructing Privacy: And Putting it Back Together Again, 17 SoC. PHIL. \& POL. 1 (2000), and Richard A. Epstein, Privacy, Publication, and the First Amendment: The Dangers of First Amendment Exceptionalism, 52 STAN. L. REV. 1003 (2000).

234. For the dangers of the expectation arguments in tax incremental financing, see City of Chicago v. Prologis, 890 N.E.2d 639 (Ill. App. Ct. 2008), cert. granted, 900 N.E.2d 1116 (Ill. 2008). For my critique, see Richard A. Epstein, How to Undermine Tax Increment Financing: The Lessons of ProLogis v. City of Chicago, 77 U. CHI. L. REV. (forthcoming 2010). 
with respect to eavesdropping. Keeping these basic intellectual building blocks in social solution produces far greater value than their privatization-unless you would like to rent out the right to use the Pythagorean Theorem. But within this framework, we want individuals to claim all potential uses that fall within the outer boundaries of their patent or copyright, subject to the other limitations appropriate to the field. The more that creators can claim within these boundaries, the quicker these innovations will be successfully commercialized.

In connection with the DataTreasury patent, the actual patents referred to all documents in one case and to checks in another. But even if checks had not been explicitly included, what potential inventor would ever give away uses to some unspecified class of documents, say to forms of electronic transfer that have yet to be devised? Virtually every contract on that copyright has explicit provisions that cover new media, which is a known unknown and not an unknown unknown, only the latter of which are the sort that could not influence incentives. Allowing legislation to carve out first this and then that exception to a valid patent is an invitation to ceaseless politics. And the only way that dubious maneuver obtains a patina of respectability is through the sorry state of the Penn Central doctrine in its home turf of real estate transactions. And so it is that the same doctrines that infect the law of takings for tangible objects work their same untoward influence into the world of intellectual property.

\section{CONCLUSION}

This Article has examined at great length one of the fundamental questions of property law: to what extent does a unified set of principles apply to both physical and intellectual property? I have written this Article in order to rebut the all too common claim that the current system is in a state of massive intellectual disarray that heralds its incipient demise. But this diagnosis is faulty, for virtually all of the current malaise in dealing with both tangible and intellectual property stems from the failure to keep to the coherent rules of acquisition, exclusion, alienation, regulation, and condemnation that are called for by the classical liberal system that always seeks to find a middle way between the unduly robust property rights of a pure libertarian system that does not easily accommodate antitrust, eminent domain, or taxation, and a gloppy communitarian system that robs property rights of their most durable and desirable social properties.

Contrary to the doomsayers, any system of tangible and intangible property rights that hews to classical liberal conceptions runs no risk of collapse or disintegration. Rather, the proper understanding of these two systems and their interconnections start from a common aspiration-to figure out a system of rights allocation to maximize the overall value of assets held in private hands. Historically, the rules for physical property evolved earlier, and typically in response to technological change. There was no permanent occupancy of land 
until agriculture became viable, for example. But it is clear that both systems draw nourishment from the classical liberal account of property that gives to the owner of anything tangible the exclusive rights of possession, use and disposition. These rights are typically of infinite time horizon for tangibles, but of limited time horizon for patents and copyrights for the reason stated above.

In working out both systems, it is important to be aware that the so-called "formal" rules of property law have strong functional justifications, deriving from the simple maxim, "coercion no, cooperation yes," which cautions against the use of forced transactions in both areas. Only a system of definite rights that are neither increased nor decreased through voluntary transfers can achieve that end. The strongest elements of the legal system are those which adhere to that simple maxim in all areas. Unfortunately, modern academic thought all too often seeks to deconstruct the rules for tangible property, rendering the field more opaque and less coherent than it should be. That similar confusion easily carries over into patents and copyrights, where modern decisions work to undermine the rights of exclusion and disposition so essential to the private law, and to undercut the protection of private property against government regulation.

None of these developments are dictated by either economic theory or modern social circumstances. All too often the defenders of the modern rules are guilty of this intellectual lapse. There is a lesson that we should learn about charges of conceptualism and formalism. Often, these roll easily off the tongue. But before these criticisms are accepted, it always has to be asked whether formal rules have a functional justification. Fortunately, in many cases, these do. By setting out clear boundary lines between parties they allow individuals to organize their affairs with greater clarity than is possible under "pragmatic" legal regimes, whose multi-factor tests often add unneeded uncertainty in the articulation of legal rules. The stakes of getting the right analytical approach are real. To confuse the voluntary division of property with the disintegration of property is to make a deep conceptual error that any well-ordered legal system should strive mightily to avoid. So long as we understand how all the pieces in this complex system work together, we can dismiss as premature any obituary for the classical conception of property rights. 
